\title{
A case study of critique: Critical perspectives on critical accounting
}

\author{
Jesse Dillard \\ School of Accounting and Commercial Law \\ Victoria University of Wellington \\ Wellington, NZ \\ and \\ Dixon School of Accounting \\ University of Central Florida \\ Orlando, Fl \\ jdillard@pdx.edu
}

and

\author{
Eija Vinnari \\ School of Management \\ University of Tampere \\ Tampere, Finland \\ eija.vinnari@uta.fi
}

We would like to acknowledge the helpful comments provided by Judy Brown, Steve Sutton, Matthew Holt, Kazeem Akinyele, Jared Koreff, Cynthia Jeffrey. 


\begin{abstract}
As accounting academics, we have a responsibility to act in the public interest as conscience, critic and counselor of society regarding economic, social and environmental justice. In fulfilling this responsibility, we are concerned with how accounting, accountants, and accountability regimes can facilitate democracy by serving the needs of pluralistic communities, giving particular attention to the various underserved constituencies. Informed by Flyvbjerg's (2001) notion of phronetic social science research that matters, we reviewed 353 articles published in Critical Perspectives on Accounting from 1990 to 2014 identifying the focal constituency(s), the injustice(s) addressed, the groups or institutions responsible for the injustice as well as the proposals for social and political praxis outlined in the studies. Our review indicates that generally the studies identify a somewhat focused, though salient and appropriate, set of economic, social and/or environmental injustices experienced by various constituencies, and to some extent, the studies consider the context and conditions that perpetuate the inequality and injustices. However, as the field matures, there is a need for more robust development of the social and political implications of critical accounting research and for articulating the ideas and implications as action programs. Further, our review suggests that several relevant constituencies such as non-human animals, children, future generations, developing nations, and gender and sex/uality minorities have received little or no attention in the current literature.
\end{abstract}

Keywords: phronetic critical accounting, phronesis, pluralism, Flyvbjerg, constituencies 


\section{A case study of critique: Critical perspectives on critical accounting}

\section{Introduction}

As academics, we have a responsibility to act as conscience, critic and counselor of society. In fulfilling this public interest responsibility as accounting academics, we are primarily concerned with how accounting, accountants and accountability regimes facilitate more democratic institutions and processes that serve to enhance economic, social and environmental justice. As critical accounting academics, we are committed to serving the needs of pluralistic communities, giving particular attention to the various underserved constituencies. ${ }^{1}$ Critical perspectives on accounting ${ }^{2}$ represents a unique lens through which to view accounting, humans and other living beings, organizations and society. It is a lens with roots in social critique and praxis and initially arose from groundings in historical materialism and political economy, or at least these origins appear to have provided the initial energy. It follows then that the purpose of critical accounting research is to enhance economic, social and environmental justice through more democratic ${ }^{3}$ institutions and processes. In fulfilling this purpose, critical accounting research heightens the awareness of various constituencies as well as society more generally to the need for, and the possibility of, programs for effective political action.

There are many permutations on this theme (e.g., enlightenment, empowerment, emancipation; educate, organize and agitate; critical theorems, processes of enlightenment, selection of strategies), much variation on how it should be understood and applied, and extensive debate as to its efficacy (see Broadbent and Laughlin, 2013; Roslender and Dillard, 2003). However, we propose that raising awareness of the current less than satisfactory state of affairs and investigating the causes and conditions thereof enhance the possibilities for recognizing impediments to freedom. Enlightenment should be the basis for developing strategies and means for moving beyond the current state, enhancing the possibilities for attaining a higher degree of individual and group autonomy exercised within a more democratically governed society. ${ }^{4}$

\footnotetext{
${ }^{1}$ See Cooper (this volume) for an enlightened and detailed discussion of the responsibilities of an academic.

${ }^{2}$ Critical perspectives on accounting is somewhat of a contested term, especially as it relates to interdisciplinary perspectives on accounting (See Broadbent and Laughlin, 2013, esp. Chapter 1; Roslender and Dillard, 2003) and an issue beyond the scope of this discussion. Suffice it to say that we see critical perspectives on accounting as an explicitly radical, politically engaged program that involves change directed at facilitating more democratically governed societies - radical in intent (moving beyond the status quo) and political in sensibilities (recognizing power as central in any social system).

${ }^{3}$ Democracy can take many forms (e.g., see Held, 2006), an issue beyond the scope of this discussion. We use the term in a generic sense to refer to participatory governing processes and institutions.

${ }^{4}$ See Dillard (1991) for a discussion of the possibilities and limitations of such a view.
} 
Our purpose is to consider the efficacy of critical accounting research as represented in Critical Perspectives on Accounting (CPA) from its inception in 1990 regarding its contribution to facilitating democracy by serving the needs of pluralistic communities. In other words, have we, as a community, carried out research that matters? This leads to the question of what are the appropriate criteria for making such an evaluation. ${ }^{5}$ Is a more democratic society indicated by: the number of laws introduced, passed, changed; the extent to which the status quo is challenged and disturbed; the achievement (or not) of a more equitable (re)allocation of resources; the facilitation of progressive social programs; contributions to less unsustainable corporate behavior regarding the ecosystems and social systems; reduction in the exploitation of various constituencies; disassembling of Western capitalist hegemony; and/or facilitating democratically governed societies? Upon reflection, using macro factors associated with facilitating democracy to access the efficacy of critical accounting research appears to be a fool's errand. Objective measures of such nebulous social phenomena are difficult, if not impossible, to identify and/or construct. Even if we could construct valid measures, establishing causal relationships might be even more problematic.

Instead, we have chosen to focus on serving the needs of pluralistic communities. Employing Flyvbjerg's (2001) proposed phronetic ${ }^{6}$ social science as a facilitating lens, we review a sample of 353 articles that comprise those appearing in every third volume of $C P A$ beginning with Volume 1 published in 1990. Our intention is not to undertake a comprehensive review but to recognize the content and direction of critical accounting research appearing in CPA since its inception. We evaluate the work in terms of the constituencies addressed (given voice), the injustice(s) considered, the entity or institution criticized as being responsible for the injustice as well as the social and political praxis outlined. We classify the articles using five categories or themes: betraying the public trust - accounting, accountants and the public interest; deceptive advertising - hegemonic ideologies; looking within - a critique of the accounting academy; explicit injustice - underrepresented, oppressed and exploited groups; and making injustice visible - corporate responsibility.

We are concerned with the past in that it can provide some guidance for the future, not to criticize or to second guess the issues studied or the principal constituent group addressed. From our analysis, it appears that most critical studies have focused on critique, that is, identifying problems with little or no discussion of the social and political implications of their findings. Also, there is a need for more research addressing underrepresented communities such as, for

\footnotetext{
${ }^{5}$ As pointed out by Steve Sutton, in light of the objectives set by the editors in the inaugural issue of the journal (see pages 1-3), the journal has met them. However, one might surmise that these objectives associated with providing an outlet for alternative, critical perspectives are intended as means toward ultimately enhancing economic, social and environmental justice.

${ }^{6}$ Following Flyvbjerg (2001, e.g., pages 56-57), phronetic is derived from phronesis, one the Aristotle's three intellectual virtues, the others being episteme (analytical rationality) and techne (practical instrumental rationality). Phronesis is claimed to be the most important in that it provides the value-rationality necessary to balance the instrumentality of the other two. Also, see Lehman (2014) for a discussion of phronemos in another context.
} 
example: non-human animals; children, future generations; developing nations; and gender and sex/uality minorities (GSM) ${ }^{7}$. $^{.}$

The discussion is organized as follows. Section two proposes Flyvbjerg's (2001) conceptualization of a phronetic social science with its emphasis on power, conflict and praxis as a useful context for considering critical accounting research. The third section provides a summary of our review of the work published in CPA. Section four discusses phronetic critical accounting in light of our review and considers its implementation. Section five provides a brief summary and reflections.

\section{Phronetic social science}

Social science studies social integration via social systems - how and why human beings come together to accomplish common goals. Collective systems require some form of communication and processes for reaching an understanding. Agreement may be reached through consensual means or it may be explicitly, or implicitly, imposed by force. A consensus maybe reached through open democratic dialogue and debate or it may be obtained through deception, rhetoric and strategic manipulation. Ideally, social systems attempt to implement democratic processes that ensure all involved have input to decisions that affect them, have the opportunity to evaluate the outcomes, and expect to be held, and to hold others, accountable. We are concerned with how critical accounting research as a branch of social science can best facilitate these objectives, that is, doing research "that matters".

Phronetic social science, as conceptualized by Flyvbjerg (2001), provides a useful characterization of "social science that matters". Following Flyvbjerg (2001, esp. chapter 5), phronetic social science concerns what is good for human beings ${ }^{9}$ as the modality for action and refers to practical value rationality as the appropriate means for relating values to praxis (i.e., values-guided action). Phronetic social science is pragmatic, requires engagement between the theoretical and the concrete, calls for experience with and in the action space, and requires reflection, judgment and choice. More specifically, Flyvbjerg (2001:60) characterizes a phronetic approach as one concerned with "carrying out analyses and interpretations of the status of values and interests in society aimed at social commentary and social action, i.e., praxis." This approach asks: Where are we going? Is this desirable? What should be done? Who gains and who loses brought about by which mechanism of power? "The task of phronetic social science is to clarify and deliberate about problems and risks and to outline how things may be done differently, in full knowledge that we cannot find ultimate answers of these questions or even a single version of what the questions are" (Flyvbjerg, 2001:140).

\footnotetext{
${ }^{7}$ We intend for this to be an inclusive term including lesbian, gay, bisexual, transgender, queer, intersexuality, etc. (E.g., see http://itspronouncedmetrosexual.com/2013/01/a-comprehensive-list-of-lgbtq-term-definitions)

${ }^{8}$ This listing does not imply that these communities are conceptualized as homogenous groups.

${ }^{9}$ Later, we expand the application beyond human beings as we relate the wellbeing of humans to the wellbeing of non-human animals and argue for the inherent value of animal life more generally as well as the interconnectedness of sustainable economic, social and environmental systems, but for the moment, we keep the language in which Flyvbjerg presents these ideas.
} 
The assumptions of phronetic social science research follow generally from a social constructivist perspective in that: the researcher is partially produced by, yet distinct from, the cultural practices studied; practices are more fundamental than discourses; and discourses are understood as part of the ongoing history of society (Flyvbjerg, 2001:115). Flyvbjerg argues that the extant research demonstrates the contingent nature of what are traditionally seen as unchanging institutions and practices, illustrating the socio-historical construction of the present perceived reality and revealing unrealized possibilities for change. The objective of phronetic research is not "definitive, empirically verifiable knowledge" but "input for ongoing social dialogue and social praxis" (Flyvbjerg, 2001:115), recognizing the significant influence of power and the presence of irresolvable conflict in the dialogic process.

Flyvbjerg (2001:131-2) proposes a pragmatic, encompassing and dynamic conceptualization of power ${ }^{10}$ that recognizes process and structural components reflected in who exercises power and how they exercise it. Power is seen as productive and positive as well as restrictive and negative and is comprised of "a dense net of omnipresent relations". Power is located both in "“centers' and institutions" and as a resource that can be "possessed". Flyvbjerg sees power as something that can be appropriated and reappropriated in an ongoing dynamic of strength, tactics, and strategies, and there is an ongoing and reciprocal relationship between power, knowledge, rationality and truth, each related to the other's production and reproduction. $^{11}$

Flyvbjerg (2001, esp. Chapter 9) outlines a set of generally pragmatic guidelines for phronetic social science research that above all "effectively deals with public deliberation and praxis", adding the caveat that the guidelines are not to be interpreted as imperatives but at most "cautionary indicators of direction" (:129). ${ }^{12}$ We depict the proposed guidelines as follows.

1. Employ value rationality by asking:

○ Where are we going?

- Is it desirable?

- What should be done? ${ }^{13}$

2. Identify the power relationships and networks by asking:

○ Who gains?

○ Who loses?

\footnotetext{
${ }^{10}$ Flyvbjerg claims to combine "the best of a Nietzschean-Foucauldian interpretation of power with the best of a Weberian-Dahlian one" (2001:131).

${ }^{11}$ Flyvbjerg (2001:132) notes that "[a]nalyses of power following this format cannot be equated with a general analytics of every possible power relation. Other approaches and other interpretations are possible. They can, however, serve as a possible and productive point of departure for dealing with questions of power in doing phronesis."

${ }^{12}$ Flyvbjerg (2001) acknowledges the primary reliance on his reading of Aristotle and Foucault supplemented by his reading of Bourdieu, Greetz, MacIntyre, Rorty and others, who, Flyvbjerg claims "emphasize practical before epistemic in the study of humans and society" (:130). Thus, while Flyvbjerg relies heavily on Foucault, we see these guidelines as pragmatic and useful for alternative theoretical and methodological perspectives.

${ }_{13}$ Values are the socially and historically conditioned common views of a group. The legitimacy of alternative value sets is decided based on the justification for the strength of the validity claims set forth for each alternative. Again, these claims are evaluated based on the socially and historically conditioned context.
} 
○ Through what kind of power relationships?

- What possibilities are available to change existing power relationships?

- What kind of power relations are those asking these questions themselves a part?

- Who governs?

o What rationalities are at work when those who govern govern?

3. Understand the context by consciously engaging the subjects and surroundings throughout the process so as to understand where the practices take place

4. Begin by identifying local micro practices, which constitute the field of interest

5. Focus on actual daily practices as well as discourses - what are the participants doing as well as what are they saying?

6. Study concrete cases to gain in depth situational knowledge as the basis for applying practical rationality and judgment (praxis)

7. Engage in narrative (storytelling) analysis asking "How" as well as "Why"

8. Consider agency, structure and their interaction so as to integrate practices with context to holistic descriptions and understandings

9. Recognize the necessity of engaging many constituencies with the objective of providing input for ongoing social dialogue and praxis.

These guidelines are designed to aid in the "pragmatically governed interpretation of the studied practices." One anticipated outcome is "to provide concrete examples and detailed narratives of how power works", its consequences, and how changes might yield alternative consequences. We interpret these guidelines as focusing on two general areas. The first two questions attempt to identify value and power networks that constitute the action space within which agents function. The remaining seven are a somewhat pragmatic re-emphasis of interpretative research methodology (e.g., see Broadbent and Laughlin, 2013), which are consistent with the ontological and epistemological positions of the pragmatic constructivistpoststructuralist view taken by Flyvbjerg and are designed to assist in identifying and articulating the concrete examples and developing the detailed narratives. While we are sympathetic with these interpretivist positions, we also recognize the validity of alternative methods and methodologies in critical accounting research. What we do feel is necessary is to deal directly with what we see as the primary components of phronetic social science - power and its relationship with values as they comprise the political context for action.

As noted earlier, we employ the general tenets of Flyvbjerg's phronetic social science in surveying the critical accounting literature. From our interpretation of Flyvbjerg's ideas as reflected in the preceding discussion, we formulate four questions or criteria for evaluating the work found in CPA:

1. What are the specific injustices (problems or risks) identified?

2. What values and interests are associated with the injustice?

3. What group is disadvantaged and what group is responsible for the injustice (what are the power relationships and how are they instantiated)? 
4. What are the recommendations arising from practical rationality and judgment (praxis)?

Next, we turn to our analysis of the work found in $C P A$.

\section{Critical accounting research that matters?}

We evaluated 353 CPA main research articles and related commentaries. Beginning with the first volume in 1990 and selecting every third year through 2014, we reviewed a total of nine volumes that included 58 issues. Using the four questions or criteria distilled from Flyvbjerg's (2001) phonetic approach as a sensitizing framework, we identify the specific economic, social and environmental injustice(s) as well as associated values and interests that the authors were attempting to clarify and deliberate ("where are we going?" "is this [direction] desirable?"). In exploring the articles, we also identify the focal constituency group as well as the group(s) or institution(s) seen to be primarily responsible for the injustices ("who wins and who loses, by which mechanism of power?"). We also identify the authors' recommendations for praxis ("what should be done?").

Our analysis of the articles identified five general themes or categories related to the issues addressed: accounting and the public interest (95) ${ }^{14}$; hegemonic ideologies (80); critique of the accounting academy (89); underrepresented, oppressed and exploited groups (36); and corporate responsibility (37). ${ }^{15}$ We elaborate on each theme identifying two or three subcategories that make up the general theme and summarize representative articles chosen as exemplars of phronetic accounting research in that they provide recommendations for social and/or political praxis. Table 1 summarizes the phronetic features of each of the ten exemplar studies. Graphs are presented for each of the general themes showing the percentage ${ }^{16}$ of articles associated with that theme in each year as well as each of the subcategories. The categorization of the articles reviewed is presented in Appendix I and a graph depicting the actual numbers appearing in each volume reviewed is presented in Appendix II.

$* * * * *$ Enter Table 1 here $* * * * *$

The classifications themes are the result of our analysis of the articles reviewed and represents one many that could be developed and fruitfully employed. We used our judgment in assigning articles to categories. If an article addressed multiple themes, it was assigned to the category we judged to be the author's primary focus. Each author evaluated the articles and disagreements were identified and resolved. However, the subjectivity of the process should be recognized. A further caveat is that we sampled only about one third of the total articles

\footnotetext{
${ }^{14}$ Number of articles associated with the classification is presented in the parentheses.

15 The sixteen (16) omitted articles included ones that, in our view, could not be classified into any of the categories because either the topic was unclear or they were not critical/emancipatory in spirit.

${ }^{16}$ Percentages are used because the total number of articles differs from volume to volume.
} 
published in $C P A$. While we have no reason to suggest that these are not representative, the extent to which this is the case was not formally determined.

\subsection{Betraying the public trust - accounting, accountants and the public interest}

This first major theme critiques the willingness and ability of the accounting profession and the related standards to provide relevant, accurate, timely and understandable financial information to society generally concerning the actions and operations of (work) organizations, and the accounting related theories that underpin them. The percentage of articles associated with this category are presented in Figure 1.

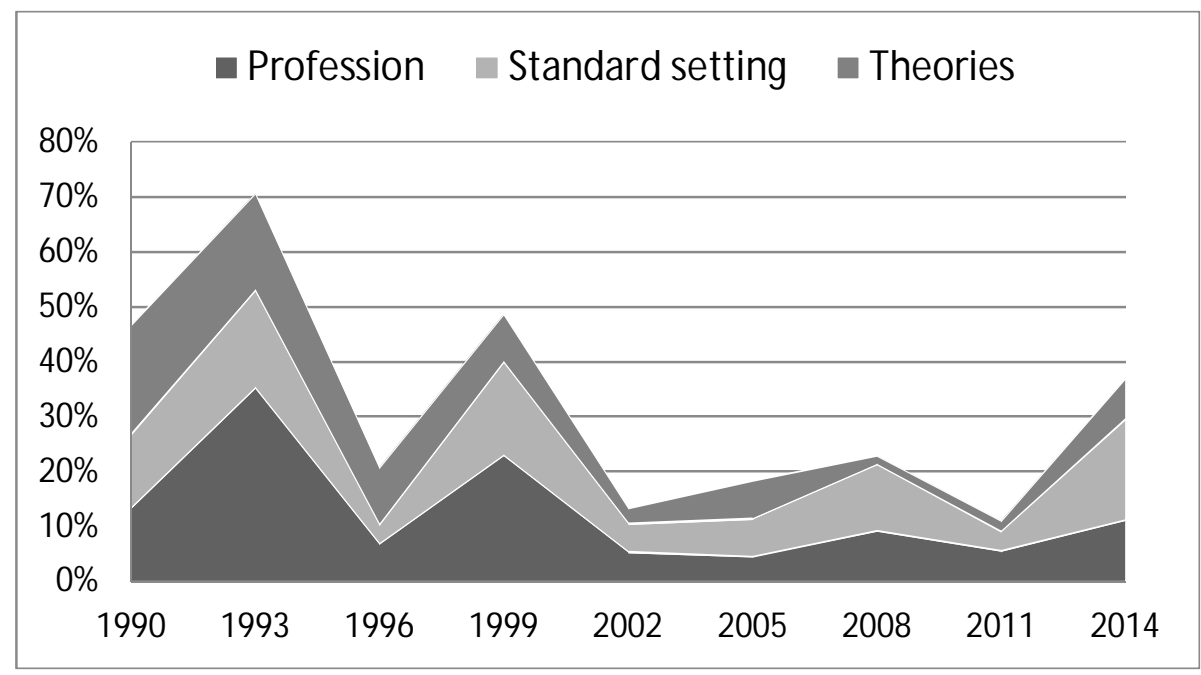

Figure 1. Percentage of articles related to accounting profession, standard-setting and theories.

\subsubsection{Accounting, accountants and the public interest}

The first subcategory contains studies related to the accounting profession and its public interest responsibility. Since the launch of $C P A$, regularly occurring scandals especially in the financial sector have prompted claims that the accounting profession has abdicated its responsibility to act in the public interest (Briloff, 1990), siding with their clients (Briloff, 1993; Lee, Clarke \& Dean, 2008) and promoting their own and their clients' self-interest over public interest (Mitchell \& Sikka, 1993; Dellaportas \& Davenport, 2008). Critical commentaries have also addressed the accounting profession's quest to reduce their own risks (Miller, 1999) or their liability, a topic which was devoted a Special Issue in 1999 (Vol. 10, issue 3). More recently, others have probed the moral and ethical ambiguities associated with both internal and external auditing as well as contemplated means to overcome them (Everett, Green \& Neu, 2005; Everett \& Tremblay, 2014a, b; Boyce, 2014; Nickell \& Roberts, 2014, Lehman, 2014).

An example that in our view reflects the spirit of phronetic research is the work by Cousins, Mitchell and Sikka (1999). Cousins et al. (1999) examine the UK auditing industry's demands for liability concessions which would not have entailed corresponding increases in public accountability or auditor duties. Appealing to the profitability effects of increased 
insurance fees resulting from "unfair" lawsuits, the UK auditing industry sought legislative changes that would have, among other things, capped the liability of auditors to third parties, made it possible for auditors to negotiate the extent of their liability with directors and required directors to take out liability insurance for the purpose of seeking compensation from other sources than auditing firms. Supported by trade associations, auditing firms threatened that if their requirements were not met, they would to move their UK business to the tax haven of Jersey. Cousins et al. (1999) note the industry's audacity in light of the fact that it already enjoyed: a state-guaranteed monopoly in certifying external audits; the option to organize as limited liability companies; and the ability to operate under a modified form of proportional liability. "It seems that the auditing industry wants secrecy, tax perks and liability concessions without commensurate public obligations." (Cousins et al., 1999: 291)

The authors then systematically critique the UK auditing industry's arguments, for instance by presenting data which evinces that the industry's claims regarding increased liability costs are false. Finally, the authors, two of whom were members of Parliament at the time of writing, outline a number of policy measures for further consideration. These include, among other things: establishing an independent regulatory function for the auditing industry; encouraging citizens to monitor the industry and to require that it be made accountable to the public; enabling citizens to file class action lawsuits; and awarding individual stakeholders and/or their nominees the right to examine audit files and ask questions about the conduct of audits. Thus, in phronetic terms, the societal problem or risk Cousins et al. wish to highlight is increasing corporatization, locally manifested as the UK auditing profession's attempt to wield the power of its network to the detriment of the citizens, and the solutions the authors outline involve reinforcing the profession's public interest responsibility through legislative and regulatory changes.

\subsubsection{Accounting and auditing standard setting and regulation}

The second notable theme related to the practice and the practitioners of accounting is accounting and auditing standard setting and regulation. Articles belonging to this category examine, for instance, the effects of implementing individual standards (Cooper et al., 1996; Shapiro, 2002; Touron, 2005) or the enactment of new legislation, especially the Sarbanes-Oxley Act (Riotto, 2008; Canada, Kuhn \& Sutton, 2008). Others have focused on more abstract issues, such as standard-setters' conceptual frameworks (see debate initiated by Bryer's Marxist critique in 1999 (Vol. 10, issue 5); Zhang \& Andrew, 2014) or the political maneuvers and lobbying associated with standard-setting processes (Cousins \& Sikka, 1993; Bengtsson, 2011; Crawford et al., 2014; Hoffman \& Zülch, 2014). A few papers have also explored the effect of different cultural contexts on the implementation of international accounting standards (McLullich \& Sucher, 2002; Cieslewicz, 2014).

An example of phronetic research addressing accounting and auditing standard setting and regulation is Shapiro (2002), which critiques an individual standard, the FASB's Statement of Financial Accounting Standard (SFAS) 106 concerning employers' accounting for postretirement benefits other than pensions. According to Shapiro, the major rationale for the 
introduction of SFAS 106 was to make employers' increased retirement-related health care commitments more visible to stakeholders such as creditors and investors by requiring employers to estimate and report the associated expected costs and liabilities on an accrual basis. The injustice addressed concerns the fact that the introduction of SFAS 106 in 1990 was followed by employers terminating or amending their retiree health plans without forewarning employees. Shapiro offers a three-stage critique of the standard, identifying the surrounding accounting and legal structures as being the institutional entities ultimately responsible for the injustice. Based on a review of pertinent US legislation and court decisions, Shapiro posits that postretirement benefits do not meet the criteria for pension plans but instead should be understood as nonlegally binding welfare plans, which employers are allowed to modify unilaterally, and therefore they should be reported as footnote contingencies instead of accrued liabilities. He then moves on to conduct a speech act analysis informed by Habermasian ideas to illustrate that, contrary to the presumption of SFAS 106 of benefit plans being understood by both parties, the language in employers' written health care plans is replete with technical terms and may be interpreted by employees to indicate that their health care continues indefinitely. Shapiro also criticizes SFAS 106 for concealing the contingent nature of employers' health care obligations and for not requiring disclosures that would clearly inform labor of employers' commitment to continue their health care plans. As a solution to the perceived omissions and to increase transparency, he suggests that auditors be required to produce a report addressed to both active and retired employees, clarifying the nature, extent and uncertainty of an employer's postretirement health care plan. Thus, the societal problem identified by Shapiro concerns an ideological standard produced by institutions that disregard the interests of labor, and the recommendations for social and political praxis involve regulations increasing understandable disclosure to employees.

\subsubsection{Legitimating accounting theories}

The third theme we identified relates to fallacies in current accounting-related theories such as the Capital Asset Pricing Model (McGoun, 1993), the Efficient Market Hypothesis (Rosen, 1990; Soufian, Forbes \& Hudson, 2014), mainstream finance theory (Hudson et al., 1999; Coleman, 2014), Positive Accounting Theory (Martens \& Stevens, 1993; Neu \& Simmons, 1996; Milne, 2002; Chabrak, 2005; Lambert \& Sponem, 2005), principal-agent theory (Ogden, 1993; Chwastiak, 1999; Mihret, 2014), as well as individual accounting measures (Jensen, 1990; McGoun, 1990).

An interesting pair of articles, Hudson et al. (1999) and Coleman (2014), considers the flaws in mainstream finance theory. Hudson et al. (1999) take as their starting point Findlay and Williams' (1985) critique of the underlying assumptions of mainstream finance theory, which in the latter's view result in discrepancies between theory and practitioner observations. The purpose of Hudson et al. is to provide a more detailed discussion and recommendations based on the concrete example of time diversification in investments. Towards this end, the authors first contrast the principles of time diversification as understood by practitioners with the mainstream models offered by Samuelson, one of the most prominent adversaries of the practitioner view. 
Generally, time diversification is supported by both empirical observations - historically stocks have performed well if kept over a long time, and theoretical considerations derived from Bernoulli's law of large numbers. According to Hudson et al., Samuelson's claims to the contrary are due to the mainstream assumptions underlying his model, while alternative assumptions derived from behavioral finance theory end up confirming the practitioner view. The authors reaffirm Findlay and Williams' exhortation that mainstream finance theorists should give up their "internally consistent but largely irrelevant models" (Hudson et al., 1999: 16) in favor of ones rooted in behavioral finance as these would possess at least some descriptive validity and could therefore offer useful insights into the operation of financial markets.

Some fifteen years after the publication of Hudson et al. (1999), Coleman (2014) returns to the topic of neoclassical investment theory, as taught and researched in higher education institutions, being out of touch with the world of practitioners. Motivated by such an apparent dichotomy, Coleman is concerned with exploring the reasons that have led to its emergence. After a discussion of the shortcomings in investment decision-making theory, Coleman presents the findings from interviews with fund managers based in Istanbul, London, Melbourne and New York regarding their willingness to apply theoretically derived decision-making models and tools in their daily work. Almost ninety percent of the interviewees indicated that they make little or no use of finance theory, citing as their main reasons that the future-oriented data required for the models and formulas cannot be accurately predicted and that theory simply does not work in practice. The fund managers also maintained that theoretical tools do not take into consideration data that they intuitively consider important, such as information acquired during firm visits, and expressed their preference for an approach to decision-making that relies on their individual skills and takes qualitative data into consideration. Based on these findings, Coleman argues for the need to test existing theories against real-life data, discard failing ones and ultimately develop and validate a new finance paradigm.

Although it may not be apparent at a first glance, the two articles are clearly in line with the ideas of phronetic research. Both Hudson et al. (1999) and Coleman (2014) identify neoclassical finance theory's inability to explain real-world phenomena as a problem that prevents a fully developed understanding of market operations. The societal risk that lies therein is that efforts to regulate market operations or prevent the emergence of financial crises are necessarily ineffective if based on a theoretical understanding decoupled from actual practice. Both articles identify obstinate mainstream finance scholars as the group responsible for this problem and offer as a solution a considerable paradigm shift that finance scholars should embark upon.

\subsection{Deceptive advertising - hegemonic ideologies}

The second general theme contains articles that expose the ideological foundations of

purportedly objective and neutral applications of processes and technologies that maintain the power and privilege of select groups. The primary ideological critique is of the dominant neoliberal hegemony, most often manifested as neoclassical economics. Two subcategories 
identified relate to those articles addressing ideology more generally and those specifically addressing neoclassical applications in the public sector, commonly referred to as new public management (NPM). The percentage of articles associated with this general theme and the subcategories are presented in Figure 2.

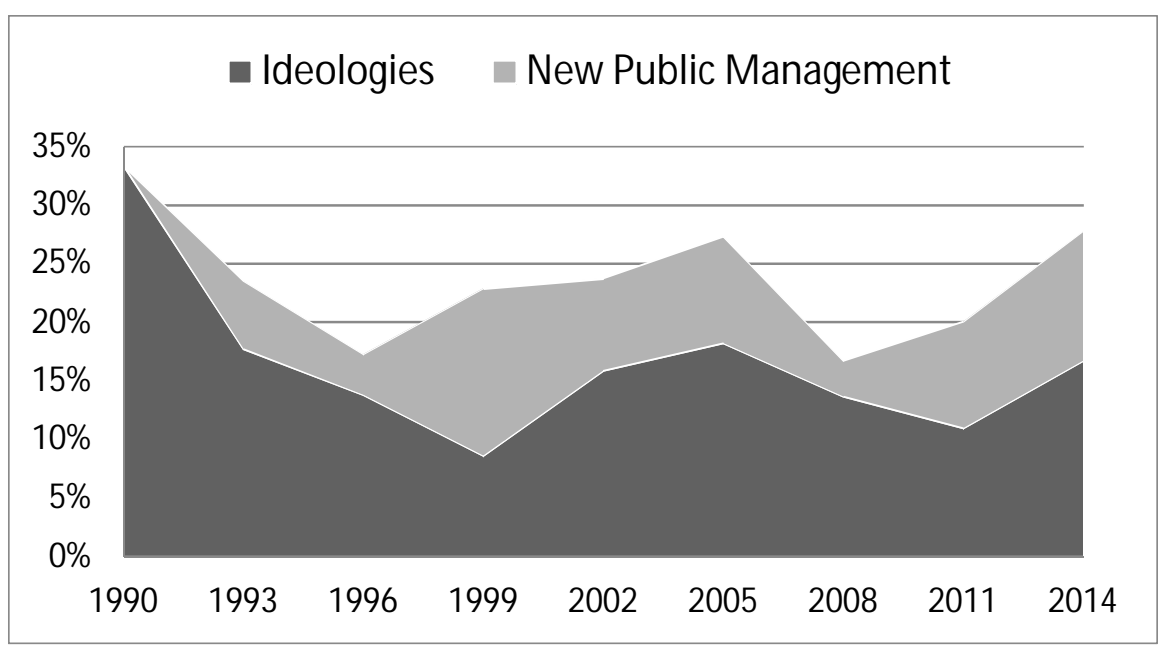

Figure 2. Percentage of articles related to hegemonic ideologies.

\subsubsection{Neoliberal ideology}

The articles addressing neoliberalism more generally identify and present a critique of the underlying ideology and investigate the effects of, for instance, capitalism (Bryer, 1993; Neu \& Taylor, 1996; Bourguignon, 2005; Cronin, 2008; Spence \& Carter, 2011), globalization (Oguri, 2005; Lehman, 2005; Otusanya, 2011), colonialism (Alawattage \& Wickramasinghe, 2008;

Bakre, 2008; Dixon \& Gaffikin, 2014) and financialization (Gleadle \& Cornelius, 2008; see also Special Issue in 2014, Vol. 25, issue 1). Within this category, we include studies that critique mainstream neoliberal hegemony in the accounting academy (Lee \& Williams, 1999; Schwarz, Williams \& Williams, 2005). Considering the abstract and amorphous nature of various ideologies, it is not surprising that only a few of the articles conclude with concrete recommendations for improving social and political praxis.

An exception to this omission of recommendations, and one of the few examples of research relating to developing countries, is Otusanya's (2011) account of the pernicious effect of globalization on wealth (re)distribution, which identifies as a societal risk the tax evasion/avoidance practices of multinational corporations (MNCs) and the subsequent detrimental effects on public investments, income distribution and general welfare in developing countries. The work examines MNCs' tactics to avoid taxation through the accumulation of capital in countries with lax or ambiguous tax legislation, in this case Nigeria. Examining the issue from a public finance perspective, Otusanya presents publicly available material from three Nigerian cases (Chevron Nigeria Ltd., Pan African Airlines Nigeria Ltd., Halliburton West Africa Ltd.) to illustrate how accounting professionals have taken advantage of legislative ambiguities related to tax evasion and tax avoidance and devised ostensibly lawful strategies 
with which MNCs have avoided paying taxes to the Nigerian government. In each of the cases, the tax income losses suffered by the Nigerian state were reported on the scale of millions of US dollars. Although tax avoidance is problematic throughout the world, the situation in Nigeria is exacerbated by the complicity in MNCs' tax planning practices of not only accounting professionals and tax experts but also the Nigerian elite and high-ranking civil officials. In Otusanya's view, the unethical activities of MNCs can only be curbed by strengthening national and international regulation to remove ambiguities that leave too much room to maneuver. The author also encourages Nigerian tax administrators to utilize already available methods for discouraging tax avoidance, such as freezing the funds owed by MNCs while a court case is pending. On a more general level, Otusanya's prescriptions include compulsory disclosures of MNCs' annual tax payments in their annual audited accounts and enabling the public to scrutinize the accounts.

\subsubsection{New public management}

The second subcategory consists of articles focusing on the operationalization of neoliberalism as New Public Management (NPM) reforms. With a firm faith in the need to reduce the size of the public sector and to increase its efficiency and accountability, the proponents of NPM, especially in the Anglo-Saxon world, but also elsewhere, have implemented comprehensive reforms targeting the governance, organization and production of public services. Naturally such major changes have been accompanied by a lively ideological debate concerning their purported benefits, a topic which has persisted in CPA ever since the mid-1990s. Commentators have considered, for instance, the ambiguous or inimical impacts of privatization (Conrad, 2005; Morales, Gendron \& Guénin-Paracini, 2014), the adoption of private sector accounting methods (Townley, 1996; Ogden \& Anderson, 1999; Mellett, 2002; Carnegie \& West, 2005; Ezzamel et al., 2014), the Private Finance Initiative (Shaoul, 2005; Benito, Montesinos \& Bastida, 2008) and public-private partnerships (Acerete, Stafford \& Stapleton, 2011). Others have highlighted the role of accounting/accountants in the commercialization of public services (Arnold \& Cooper, 1999; Caramanis, 1999; Lawrence, 1999).

As an example of phronetically driven research, Carnegie \& West (2005) focus on the perennial question of which kind of entities or characteristics it is possible and feasible to quantify. The authors examine accrual accounting and reporting reforms in Australia and New Zealand that made it compulsory for public sector accounting entities to assign a monetary value on non-financial resources such as scientific and heritage assets. Conceptually, Carnegie \& West contest the feasibility of assigning monetary values to such assets on the grounds that they are different in kind from the ones held by profit-seeking organizations. Non-financial assets are to be held indefinitely for the purpose of providing societal and cultural services without the intention of generating a profit; in addition their valuation is difficult, if not impossible, due to their unique nature. After presenting illustrative cases from museums and libraries in Australia and New Zealand, Carnegie \& West assess the consequences of the accrual accounting reforms for the public service providers' accountability to end users of financial reporting information, 
such as decision-makers and citizens. They note the paradoxical outcome that while private companies are required to broaden their scope of reporting to include non-financial information, public sector entities are expected to narrow their focus to financial information that is most often decoupled from the quality or quantity of the services provided. They argue that such reporting is consequently of little value to the service users and their political representatives. Carnegie \& West conclude by arguing that accounting professionals should be made to discharge their accountability to society by evaluating the impacts of their measurement regimes and by responding to, instead of trying to deflect, criticisms. The authors also state that the monetary valuation of many non-financial assets should simply be terminated.

In phronetic terms, the societal problem that Carnegie \& West highlight is that accounting reforms meant to increase public accountability have actually failed to do so. As their analysis identifies both structures and actors as being responsible for the implementation of ideologically imbued accounting regimes, their solutions for the perceived problem include both rescinding some of the most harmful elements of the reform and obligating accounting professionals to conduct assessments of such reforms.

\subsection{Looking within - critique of the accounting academy}

The third general theme is comprised of work that undertakes a critique of the accounting academy, highlighting issues in the processes and content of both the education and research dimensions. The percentage of articles associated with this general theme and the subcategories are presented in Figure 3.

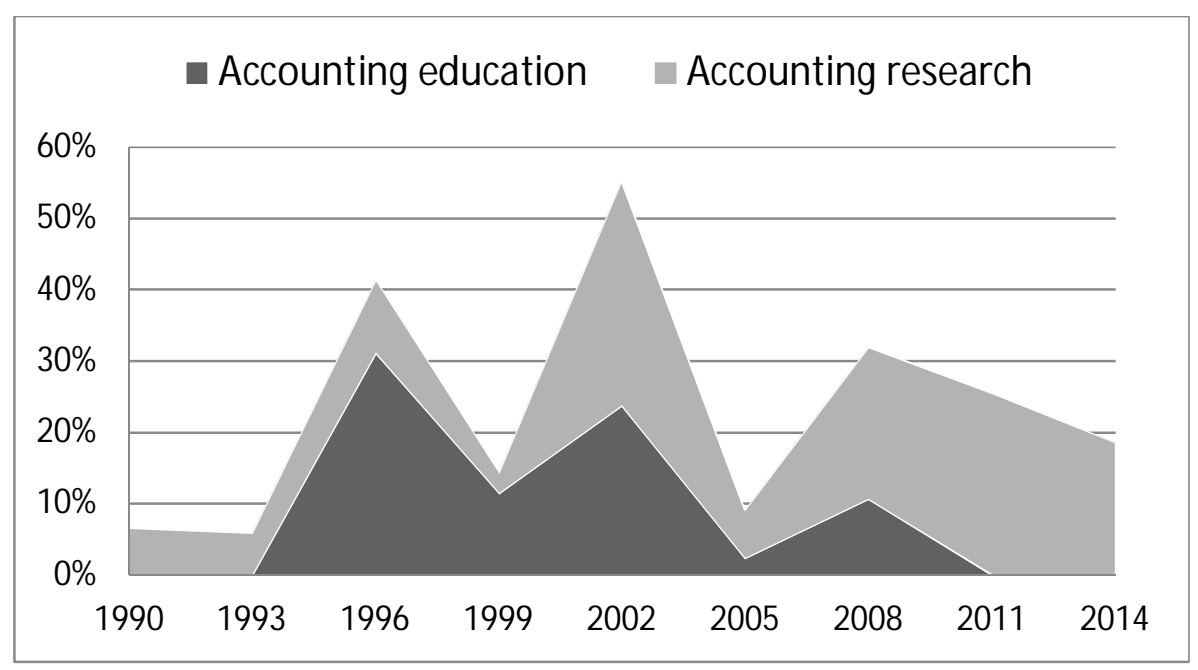

Figure 3. Percentage of articles related to accounting education and accounting research.

\subsubsection{Accounting education}

The articles focusing on education mainly highlight deficiencies in current accounting education, such as the lack of ethics and sustainability considerations in programs and curricula (Reiter, 1996; McPhail, 1999; Gray \& Collison, 2002; Boyce, 2008; Low, Davey \& Hooper, 2008), the narrow, quantification-oriented scope of accounting studies (Chua, 1996; Humphrey, 
Lewis \& Owen, 1996) and issues associated with teaching minority students (Gallhofer et al., 1999; Saravanamuthu, 2008; McGowan \& Potter, 2008; Cho, Roberts \& Roberts, 2008). Others have critically examined the ramifications of commercialization in the university sector (Dillard \& Tinker, 1996; Dominelli \& Hoogvelt, 1996; see also Special Issue in 2002, Vol. 13, issue 5). Dillard (2002) is particularly concerned with the way in which the business sector, purporting a global corporate logic, attempts to co-opt business and accounting education. The work attempts to raise awareness of ideological currents that direct accounting education away from a public-interest orientation towards focusing primarily on commercial interests. Dillard examines this development in the context of the effects of implementing total quality based accreditation standards in the United States in the early 1990s. He argues that managerialist influences, grounded in and legitimated by neoliberal ideology, embodied within the accreditation standards are clearly detectable, for instance, in the criteria for an education performance award, accounting accreditation guidelines, a professional accounting fraternity's constitution and by-laws, and the position taken by the American Accounting Association (AAA) in an education related monograph it published and distributed to its members and beyond. In a polemical appeal for retaining and reinforcing the public interest responsibility of accountants, Dillard (2002: 639) reminds accounting educators and researchers of their duty to: "articulate the contemporary socio-economic challenges brought about by the globalization of capital and capitalistic enterprises, enlighten society to the implications, and formulate and disseminate means for responding in an informed and just manner to the challenges."

On a more practical level, Dillard's suggestion for fulfilling this educational duty translates into designing accounting degree programs and courses to include analyses and critical assessments of various business practices, thus emancipating both educators and students from the dominance of managerialism and capital in contemporary Western societies. His prescriptions for the AAA include calling committees to examine the consequences of accountants' desecration of their public interest role as well as commissioning reports to indicate where professional changes would be necessary so that accountants could better fulfill their societal responsibilities. The major societal risk that Dillard sees looming ahead is that unless such improvements are achieved, we are confronted with a dystopian future where accounting educators cater to the tastes of big business by training money-driven consultants incapable of critical thinking. Thus, Dillard identifies managerialism as the threat infiltrating society through accounting education and suggests that one way the threat may be countered is by redesigning the contents of degree programs and by stipulating that the AAA bear part of the responsibility.

\subsubsection{Accounting research}

The studies focusing on research mainly offer suggestions for developing accounting research through the adoption of different paradigms (Arrington \& Watkins, 2002; Davila \& Oyon, 2008), interdisciplinary theories and concepts (Arthur, 1999; Inanaga \& Schneider, 2005; Moriceau, 2005; Gurd, 2008; Linsley \& Shrives, 2014) or different methods (Davie, 2008; Kim, 2008; Whittle, Carter \& Mueller, 2014). There have also been two significant debates 
concerning, respectively, the application of structuration theory in accounting research (see Special Issue in 2014, Vol. 25, issue 2) and the future of interpretative research (see Special Issue in 2008, Vol. 19, issue 6). The latter, "polyphonic debate" was initiated by Ahrens and a number of others (Ahrens et al., 2008) with the purpose of outlining the identity, achievements and future prospects of interpretive accounting research (IAR). Within this theme we did not identify an article that could have been characterized as phonetic accounting research.

\subsection{Explicit injustice - underrepresented, oppressed and exploited groups}

The studies classified in the fourth general theme consider economic, social and environmental injustice experienced by underrepresented, oppressed and exploited groups. The two subcategories identified are labor exploitation and other underrepresented disadvantaged groups. The percentage of articles associated with this general theme and the subcategories are presented in Figure 4.

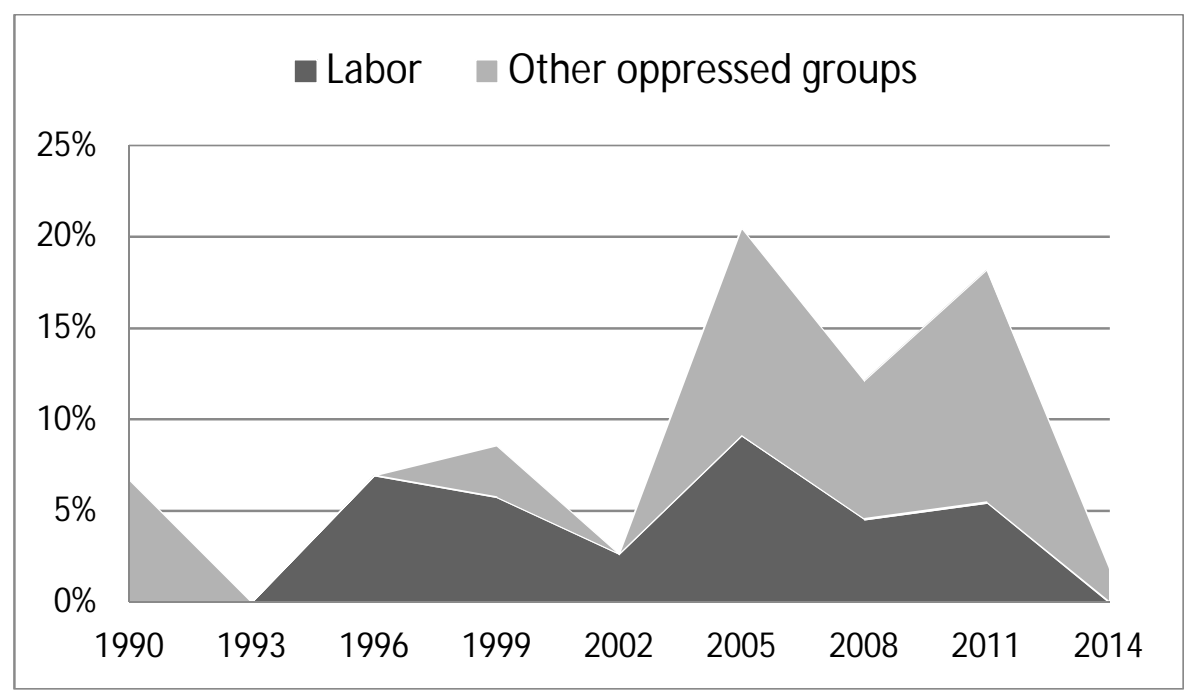

Figure 4. Percentage of articles related to labor and underrepresented groups.

\subsubsection{Labor exploitation}

The articles related to labor exploitation include investigations of traditional wage labor, often in the context of managerial control systems (Bessire \& Baker, 2005; Bourguignon \& Chiapello, 2005; Wickramasinghe \& Hopper, 2005) but also in relation to social psychological phenomena such as humiliation (Czarniawska, 2008) and bullying (Armstrong, 2011). Other labor groups studied include professionals such as accountants (Roslender, 1996) and accounting academics (Cooper \& Puxty, 1996; Lawrence \& Sharma, 2002).

An example of a phronetic orientation related to labor exploitation is represented by James (2008). He examines the trials and tribulations facing entry-level accounting academics in Australian business schools, who have not attained a $\mathrm{PhD}$. The analysis is based on his personal experiences as well as those of colleagues and a survey administered to $\mathrm{PhD}$ students in Australian universities. The societal problem he identifies is that junior faculty members are 
heavily burdened by administrative and teaching tasks, while simultaneously being bullied by administrative personnel and pressured by senior faculty to initiate $\mathrm{PhD}$ research on topics that they often do not find intriguing and that may even conflict with their personal values and ethical views. James thus perceives structural factors as leading to junior academics becoming locked up in a Weberian iron cage of uninteresting topic and disinterested supervisor, from which their opportunities to escape are limited. Those who cannot adapt and finalize their PhDs need to resign and relocate to another university, take up a teaching-only position or a corporate job, or become casually teaching homemakers. Those who opt to work on casual contracts may gain more time to conduct research but are faced with accepting an income level that may be even lower than if the individual relied on welfare assistance only. The implications of James' study on social and political praxis are clear: he calls for the Australian government to make more $\mathrm{PhD}$ scholarships available both to those who want to study full-time as well as those who prefer parttime study, even in cases where the applicant's prior academic results are not perfect. His advice for junior academics is to unite forces within other disillusioned colleagues to form a counterhegemonic force to managerialist imperatives such as constant scrutiny and evaluation. In phronetic terms, the societal problem identified by James relates to the oppression and alienation of junior academic labor by powerful individuals supported by hierarchical structures. His recommendations involve both macro-level institutional reforms as well as grassroots level resistance.

\subsubsection{Underrepresented disadvantaged groups}

Besides labor, the underrepresented, oppressed and exploited groups addressed in the studies include women, indigenous peoples, ethnic minorities, the self-employed, the disabled and the citizens of developing nations. Studies with a more or less explicit feminist framing have examined, for instance, the difficulties encountered by women in the accounting profession (Ciancanelli et al., 1990; Haynes, 2008; Jeacle, 2011; Walker, 2011) or the representation of women and other minority representatives on corporate boards of directors (Bernardi, Bean \& Weippert, 2005). Those studied concerned with indigenous peoples and ethnic minorities have for instance provided historical analyses of the role of accounting in unethical practices such as slavery (Oldroyd, Fleischman \& Tyson, 2008) and land grabs (Hooper \& Kearins, 2008) or examined the present day conditions of minorities in business education (McNicholas \& Barrett, 2005; de la Rosa, 2008). Other studies have examined the financial and institutional vulnerability of the self-employed (Boden, 1999), the plight of disabled accountants (Duff \& Ferguson, 2011) as well as difficulties associated with development accounting (Jayasinghe \& Wickramasinghe, 2011).

As an example of phronetic research, consider the article by Blanco \& de la Rosa (2008) on the under representation of Hispanics in accounting education in the United States. By way of background, the authors explain that with an estimated population of 98.2 million, Hispanics are the fastest growing ethnic segment in the US and are expected to make up almost 25 percent of the population by 2050. As the integration of ethnic minorities into the educated workforce is 
crucial for social stability and economic competitiveness, Blanco and de la Rosa examine the extent to which Hispanics are represented in the student body of US business schools, traditionally considered fortresses of conservatism. The authors exhibit country-wide statistical support for their claim that, despite a steady incremental increase, Hispanics are considerably underrepresented in higher education in general and business/accounting education in particular. Narrowing their scope of inquiry to the state of Texas where most of the population growth is made up by Hispanics, Blanco and de la Rosa find that although Hispanics made up 40 percent of the university-age population in Texas in 2001, their share of public university enrollment was only 21.8 percent. Detailed business and accounting degree information from two Texas universities similarly indicates that Hispanics are notably underrepresented in these fields of education. In phronetic terms, the authors forcefully argue that the group responsible for such a state of affairs is mainly US universities, whose efforts to redress the issue constitute little more than empty speech and ceremonial gestures due to the inadequately addressed inherent difficulty of cultural integration as well as the implicit screening embedded within business schools. To reduce the risks of societal unrest and loss of economic competitiveness, Blanco and de la Rosa present a list of practical recommendations, which include both institutional measures such as evaluating university performance in recruiting and retaining Hispanic students and cultural measures such as increasing understanding of Hispanic culture.

\subsection{Making the injustice visible - corporate responsibility}

Corporate responsibility is the label assigned to the fifth general theme and refers to the willingness and ability of organizations and accountants to provide relevant, timely and understandable information concerning the social and environmental effects of their activities to various interested constituencies. The two subcategories are social and environmental accounting and reporting and corporate governance. The percentage of articles associated with this general theme and the subcategories are presented in Figure 5. 


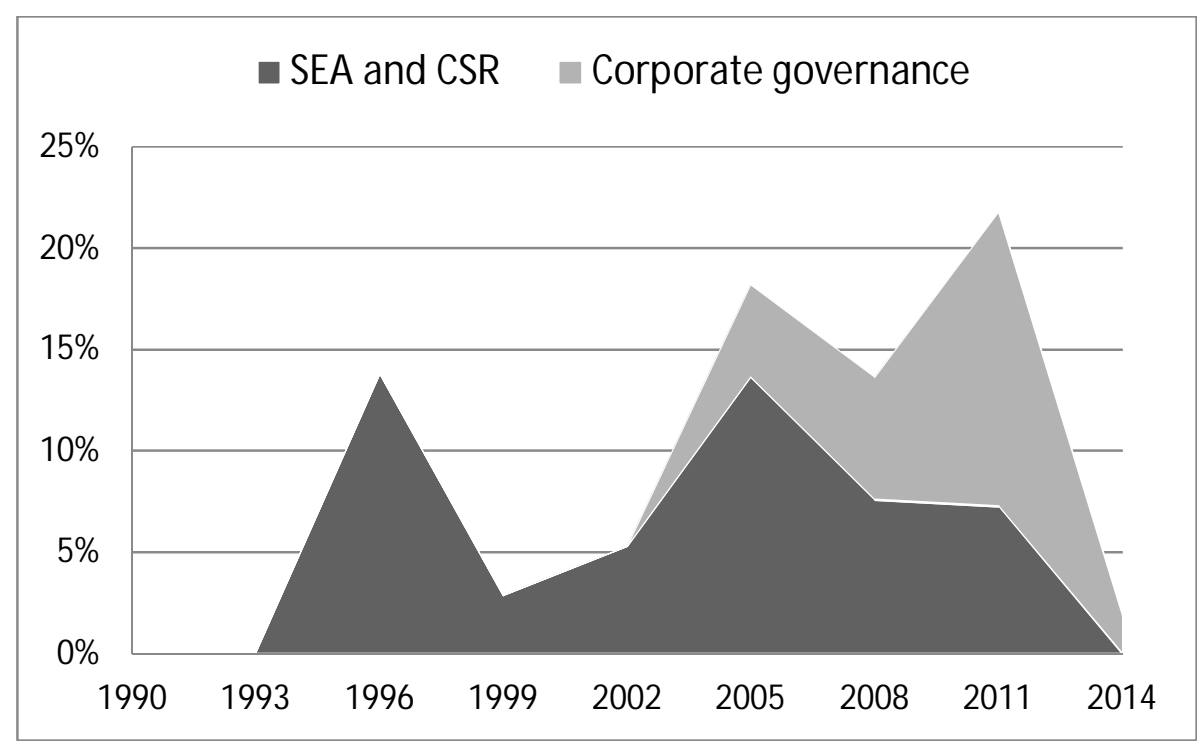

Figure 5. Percentage of articles related to social and environmental issues and corporate governance themes

\subsubsection{Social and environmental accounting and reporting}

Some of the studies associated with social and environmental accounting focus on the technical dimensions of social and environmental accounting (Gibson, 1996; Lehman, 1996; Milne, 1996; Grinnell \& Hunt, 2002) and associated reporting (Cho, Chen \& Roberts, 2008; Freedman \& Stagliano, 2008), while others have analyzed factors associated with (non)disclosure of corporate social and environmental performance (Buhr, 2001; Belal \& Cooper, 2011). Yet others have analyzed or suggested forms of accounting that would facilitate a transition towards more socially and ecologically just societies and modes of operation (Birkin, 1996; Birkin, Edwards \& Woodward, 2005; Crowther \& Hosking, 2005; Thomson \& Bebbington, 2005; Cooper et al., 2005).

As an example of phronetic critical accounting research, we consider the article by Cooper et al. (2005) on the political potential of social accounts. The local-level societal problem that the authors address relates to the exploitation of Scottish students who need to work part-time in order to finance their studies. In their work as accounting educators, Cooper et al. (2005) had noted that such students were tired and stressed and could not get study leave from their employers. To gain a more rigorous understanding of the issue, the authors conducted a survey among Glaswegian university students regarding the extent of student employment and its impacts on the perceived quality of education. The survey instrument and the social account that the authors then constructed were based on a Marxist conceptualization of capitalism and its associated power relations. The results of the study were supportive of the authors' initial hypothesizing in that students had become subject to capitalist exploitation, manifested as insufficient pay and long working hours, resulting in their becoming stressed and almost burnt out even before graduation. The social account produced by Cooper et al. (2005) received considerable media attention and its results served as a basis for an official committee report 
supporting the abolishment of tuition fees and the re-introduction of state financial support for students. Even though the Scottish government ultimately presented a watered-down version of these recommendations, tuition fees were in fact abolished in Scotland. Although their empirical material relates to a contemporary and local struggle, Cooper et al. (2005) offer social and political recommendations on a more general level, suggesting that accounting researchers support such struggles by producing theoretically informed social accounts that make visible the dominant power relations and their effects on oppressed groups.

\subsubsection{Corporate governance}

The studies that we see as being associated with corporate governance in a broad sense include those that explicitly refer to the topic (Tremblay \& Gendron, 2011), those that provide examples of how accounting is implicated in unethical, criminal or environmentally harmful practices (Lehman \& Okcabol, 2005; Stoianoff \& Kaidonis, 2005; Chwastiak, 2008; Compin, 2008) and those that examine emerging topics such as human rights (Bishop \& Boden, 2008; see also Special Issue in 2011, Vol. 22, issue 8).

Tremblay \& Gendron (2011) is particularly interesting from our perspective as the authors explicitly express their sympathies for phronetic research. In broad terms, the societal problem motivating their study is the seemingly never-ending story of corporate malfeasance being followed by tightened regulations being followed by yet another scandal. In post-Enron North America, auditors and audit committees were pinpointed as being responsible for the corporate deviancy by not having recognized it in a timely manner. Consequently, newly instituted regulations such as the Sarbanes-Oxley Act (SOX) and the corresponding Canadian regulations purportedly introduced good governance practices related to auditing and internal control, assigning specific responsibilities to the audit committees. A notable prescription in SOX is to make audit committees directly responsible for appointing, compensating and overseeing the work done by an audit firm. A similar discourse emerged from professional associations' best practice recommendations promoting audit committees' increased diligence. Considering that such prescriptions are necessarily subject to interpretation by those supposed to enact them, Tremblay \& Gendron investigate how Canadian audit committee members understood and acted upon the new regulations and professional best-practice guidelines designed to promote a stronger role for audit committees. The dominant logic exhibited in the interviewees' responses was that of resistance as they saw the new regulations as an instance of overreacting or an ineffective method to combat problems that are likely to persist ad infinitum. It is no wonder, then, that the changes effected in the audit committees tended to be symbolic and superficial in nature, while the practices associated with discussing substantive issues remained unchanged. Concerned with addressing the problem of such resistance to the spirit of the regulation taking place outside the reach of regulators and the general public, Tremblay \& Gendron (p. 271) outline their practical solutions to this problem ("what should be done?") in the form of questions: "Would it make sense to require that regulatory representatives to observe a number of audit committee meetings? Would it be appropriate to encourage surveys and 
interviews to be carried out on a regular basis with audit committee members and other attendees of committee meetings?" With explicit reference to Flyvbjerg (2001), Tremblay \& Gendron encourage other scholars to examine the backstage of corporate governance and to thus produce socially pertinent research.

Next, in light of our review, we discuss the implications for a phronetic critical accounting.

\section{A phronetic critical accounting}

We objectives of an operative critical accounting project begins with the effectively generation and communication of ideas so as to facilitate an inclusive public discussion and debate. The anticipated result provides the context wherein alternative, and hopefully superior, ideas and interpretations emerge, expanding the possibilities and opportunities for democracy by enhancing possibilities for progressive programs and action.

The means by which a phronetic critical accounting addresses these objectives is providing a context useful in recognizing, and addressing the possibilities for, and of, our constituencies. Phonetic critical accounting research seeks to articulate how current reality could have been otherwise by critically exploring historical circumstances as well as current practices. Identifying and clarifying problems and risks and recognizing the centrality of power, its possession and use, in forming and sustaining social systems, confirms the possibility for change, "in full knowledge that we cannot find ultimate answers" or "even a single version of what the questions are" (Flyvbjerg, 2001:140).

How can we imagine critical perspectives on accounting as a phronetic social science? We propose that it be informed, but not inhibited, by predispositions and past practice and firmly committed to democratic governance that facilitates a pluralistic ethos directed at overcoming economic, social and environmental injustice locally, nationally and globally. A phonetic critical accounting requires that: all affected members can understand and can be understood; alternative viewpoints are recognized and encouraged; and unresolved, and unresolvable, conflicts are identified and even accentuated; and power asymmetries are acknowledged and addressed. A phronetic critical accounting is concerned with developing the causes and conditions that create discursive space where different constituencies can be engaged and actively involved in the dialogue and debate concerning those issues and decisions that affect them. The objective is not necessarily to bring about consensus of outlook or opinion, of methodology or ideology. It is to provide input for ongoing social dialogue and debate by serving as catalyst and facilitator of action leading to progressive change by, and in, the accounting and business academy and the larger accounting and business community as well as society and its various and varied members.

\subsection{Applied through an agonistic lens}


The energy, ingenuity and politics originate in, and are sustained by, a vibrant and politically imbued critical perspective that recognizes and facilitates the many voices present. One way to envision a contesting constituency oriented phronetic critical perspective is suggested by Mouffe's agonistics $(2000,2005,2013) .{ }^{17}$ Agonistics sees the political sphere as being comprised of, and emerging from, contestations and debates motived and energized by inherent antagonisms and prevailing asymmetric power relationships. The objective is to articulate and implement democratic forms of subjectivity and individuality that facilitate citizenship grounded in democratic values within this more antagonistically conceptualized context. Different individual and collective political identities emerge iteratively in the process of identity creation and may be enhanced in the presence of asymmetric power relations and antagonisms among opposing constituencies.

Following Mouffe, we propose that currently the primary issue confronting phronetic critical accounting as it relates to its constituencies is not the ameliorating of power, or its elimination, but how to facilitate conceptualizations and constellations of power that are more supportive of and compatible with democratic values and processes. Instead of searching for some objective reality identifying commonalities and facilitating compatibility and compromise, critical accounting might better serve its constituencies by helping them better articulate and understand their position(s) on contested issues within adverse political contexts. For example, how can critical accounting facilitate indigenous people in articulating and communicating the physical and cultural implications of land use alternatives? How can critical accounting better serve the needs of labor in creating a more democratic workplace? How can critical accounting facilitate GMS groups in making a case for protecting their civil and domestic rights? How can critical accounting further the cause for racial equality? How can critical accounting give a voice to those who cannot speak for themselves, such as children, future generations and non-human animals?

Meaningful dialogue and debate among adversaries requires agreement that certain democratic principles, such as justice, equality and freedom, are important but recognizes the possibility of irreconcilable disagreements as to their definition and operationalization. A phronetic critical accounting confronts various adversarial constituencies by supporting reasoned challenges to alternative ideas and disagreeable positions. Critique, as does democracy, requires an articulate alternative or disagreeable "other". "[S]ocial conflicts ... produce the valuable ties that hold modern democratic societies together and provide them with the strength and cohesion they need; in that social conflicts are the true pillars of democratic societies" (Flyvbjerg, 2001:108). One of the privileges of democracy is to disagree and to participate in the related power struggles and conflict.

What we are proposing for a phronetic critical accounting is a politically imbued pluralism that considers its constituencies and how they might be better served instead of a specific program for research and action. Accentuating diversity, power and conflict as both

\footnotetext{
${ }^{17}$ Also see Brown (2009), Brown and Dillard (2013a,b, 2015), Dillard and Brown (2012, 2015), Dillard and Roslender (2011), for further discussion and accounting applications.
} 
organizing and operating principles facilitates the recognition of alternatives that challenge the taken for granted dominant representations. Critical accounting can provide representations and counter representations issued from different ideological perspectives, diverse interests, and strategies, reflecting asymmetrical power relationships. The objective is to recognize injustice and facilitate formulating effective responses to particular issues by making possible more authentic participation through more democratic forms and processes.

Drawing on Brown's (2009) principles for an agonistic critical dialogic framework, we briefly consider several operational characteristics important in fostering meaningful support for critical accounting's constituencies. As discussed above, phronetic critical accounting attempts to enable participation and understanding by employing practices that acknowledge varied constituencies possessing a wide range of assumptions, values and perspectives. Differences and contestations are highlighted, not reduced to seemingly common, homogenous representations. Each group is recognized as potentially having differing representations and information characteristics and needs. Phronetic critical accounting is challenged to provide its constituencies the information they need to effectively engage in relevant dialogue and debates and to present information in an understandable form. By doing so, critical accounting facilitates a participatory process advocating that all speak and state their claim in their own voices in a way that can be understood by the participants.

Developing a pluralistic attitude requires that critical accounting recognizes and challenges prevailing power asymmetries and provides means whereby marginalized groups can do so. To be effective, a phronetic critical accounting needs to recognize the necessity to learn from their constituencies through dialogue, debate and reflection related to both working with the constituency group in developing relevant representations as well as coming to understand the constellations of power within which they and the groups reside. As part of the ongoing dynamic and power struggles inherent in social systems, critical accounting should be vigilant in preventing one ideological imperative from replacing another. A pluralistic attitude is required throughout because, as Flyvbjerg (2001) argues, the ongoing construction of social reality precludes first principles and axiomatic theory that articulate social laws. In our current conceptualization of a phronetic critical accounting, the context and processes for praxis are emerging from the complex interaction of individuals, groups and social systems.

\subsection{Extending critical accounting research}

Our review and analysis of the critical accounting literature suggests that power is recognized as a central factor in understanding and responding to injustice. Further, while most authors at least implicitly acknowledge it, there appears to be a need to be more explicit about power and its role in economic, social and environmental injustice (and justice). In order to understand the influence of power, it is necessary to understand the extant power networks, which requires knowledge of their historical evolution. Recognizing the influence and implications of power and recognizing that things could be otherwise facilitates a practical response to the question of what is good and bad for human and nonhuman beings, the core 
question of phronetic critical accounting. This can best be attained from an understanding of the "socially and historically conditioned context" of general and concrete problems and struggles (Flyvbjerg, 2001:101). Such an understanding leads to the critique and identification of supposedly neutral (political) processes and institutions that (indirectly) impose undemocratic political institutions, thus, unmasking actual power asymmetries and facilitating institutional change. Recognizing the contingency of "reality" suggests that things could have been otherwise and opens possibilities for imagining progressive change.

In the studies we considered, a preponderance of the research's central focus is a critique of entities such as the accounting profession; standard-setters and/or their lobby groups; the mainstream academic community in accounting; existing accounting-related theories and frameworks; corporations, politicians and other proponents of hegemonic ideologies; as well as current accounting education and research. Few, if any, studies address GMS, children, future generations or non-human animals either within our sample or in the over nine hundred published in CPA. Next, we contemplate how might a phronetic critical accounting facilitate meaningful research in these under researched areas?

We briefly consider how we might conceptualize a project designed to give voice to nonhuman beings. The issues concerning non-human beings are wide ranging and complex, extending from a deontological position of the inherent value of animals ${ }^{18}$ as subject-of-a-life, which considers killing an animal to be as immoral as killing a human being (Regan, 1985), to a more utilitarian argument that the earth's ecosystem cannot sustain current levels of meat and dairy production due to the inefficient utilization of scarce resources. Falling somewhere in between is Nibert's (2013) argument that animal treatment from early pastoralism to present factory farming illustrates how the abuse of both tamed and untamed non-human animals to further elite interests of capital accumulation has been intertwined with subjugation of other vulnerable groups, especially indigenous peoples, ${ }^{19}$ undermining the emergence of a peaceful and just society. Thus, there appears to be a range of legitimate values based proposition to challenge the undesirable or untenable status quo. To adequately address the related issues requires a major socio-economic transition to human plant based diets. However, animal production is a deeply institutionalized practice. Power interests resisting such a transition are those operating within the meat and dairy value chain, numerous lobby groups as well as a large body of conservative politicians and civil officials. One way critical accounting research might contribute to this struggle is through examining counter accounts ${ }^{20}$ - their generation, distribution and efficacy. In this particular context, counter accounts are designed to effectively generate and communicate salient information regarding industrial animal farming so as to

\footnotetext{
${ }^{18}$ We acknowledge that human beings are animals too, but for the sake of brevity we refer to non-human animals simply as "animals".

${ }^{19}$ Consider for instance US ranchers, who systematically annihilated Native Americans and buffalos to acquire more pasture land for their cows, which in turn were ill-treated and killed by low-paid, devalued individuals; or British meat producers, who insisted that cows purchased from the US were kept alive during their long and painful sea voyage because freshly butchered meat fetched a higher market price in the UK (see Nibert, 2013).

${ }^{20}$ Counter-accounts (also known as shadow accounts or social accounts) may be defined as alternative representations of organizational activities considered harmful (Thomson et al., in press; Gray, et al, 2014).
} 
facilitate an inclusive public discussion and debate, leading to alternative (superior) ideas expanding possibilities and opportunities for progressive programs and action (praxis).

For example, if social movement activists issue counter accounts of inhumane industrial farming practices, one question that emerges is how to articulate, distribute and evaluate the impact of the counter accounts on human consumption and dietary patterns, political discourse and decisions as well as the operation of the animal industry in the local, regional and national contexts. Engaged scholarship is required as critical accounting scholars interact with other experts and the constituents involved, such as activists, politicians or representatives of meat and dairy firms. Phronetic critical accounting research engage the subjects and their surroundings so as to gain a local appreciation of the context of animal production. The investigation begins on the micro level, focusing on the actual daily practices of production and consumption by studying specific cases and contexts. The narrative analysis of such practices asks both "why" and "how", recognizing the co-constitutive nature of agency and structure. The purpose is to develop a clear, understandable narrative giving voice to all so as to effectively engage them in the dialogue and debate with the hope that new understandings and unrecognized alternatives arise. Evaluating the effectiveness of the counter-accounting project involves considering the adequacy whereby the specific injustices (problems and risks) are identified and the specificity of the values and interests associated with the injustices. From a critical perspective, the treatment of power is central. It is imperative that the disadvantaged groups, both human and non-human, be identified and the source and extent of the injustice they experience fully and clearly articulated. Lastly, recommendations for action are specified and clearly communicated based on practical rationality and judgment gained through an in depth and nuanced understanding gained from a historically grounded appreciation of the everyday practices and the influence of power thereon. Engaged scholars could for instance offer advice to the issuers of the counter accounts on how to make their message more convincing and politically effective.

\section{Summary and reflections}

\subsection{Summary}

Have we as a critical accounting community undertaken research that matters? We considered the efficacy of critical accounting research as represented in Critical Perspectives on Accounting from its inception in 1990 regarding its contribution to facilitating democracy by serving the needs of pluralistic communities. We evaluated the articles using four questions distilled from Flyvbjerg's proposed phronetic social science and identified five general themes. Two or three subcategories were identified and discussed related to each of the general themes, and illustrative examples of phronetic research presented. Critique was the primary focus of the research without much discussion of the social or political implications of the findings or development of programs for action. We then discussed the possibilities of a phronetic critical accounting - imagining critical perspectives on accounting into the future - as a means for overcoming economic, social and environmental injustice locally, nationally and globally. Such a 
critical accounting would facilitate a politically imbued pluralism that consciously considers how its constituencies, especially those disadvantaged and underrepresented groups, may be best served. Diversity, power and conflict are identified as both organizing and operating principles in challenging dominate hegemonic regimes. The objective is to recognize injustice and formulate effective responses to particular issues by facilitating more authentic participation through more democratic forms and processes. We also identified several underrepresented and disadvantaged groups that have not been adequately recognized in the extant literature.

\subsection{Reflections}

If we take Rorty's (2006) definition that progress is recognizing that we have more alternatives available to us than of which we were formerly aware, then we might conclude, at least in some limited way, that we have been successful as a phronetic social science. The work found in $C P A$ indicates reasons why our situations might be as they are by providing alternative explanations to the prevailing neoclassical ideologies. However, there is a need for more guidance or creative suggestions as to how this knowledge might be used in bringing about more democratically oriented life contexts enhancing autonomy and economic, social and environmental wellbeing. ${ }^{21}$

In engaging and evaluating critical accounting research, one quickly recognizes that reality is exceedingly more complex than our current level of theoretical representation and methodological capabilities. One constant upon which we can depend is the pulsating, throbbing centrifugal and centripetal forces of being and becoming. The means for understanding and channeling these forces for change seem to be quite another matter. What does one do when one finds oneself too myopic to accept the nullity of postmodernism, but too cynical to accept the rationality and (false) promise of modernity? We move from reality to process and back. We take a linguistic turn. We look to the universality of process or the fluidity of language and the magical emergence of universal or local constellations that we label truth(s). We look to the utopian dreams of heaven, nirvana, invisible hands, ideal speech situations, pluralistic engagement, dialogic emergence, or networks of power-knowledge.

The capitalist hegemony has proven much more adaptable and resilient than anticipated (e.g., Boltanski and Chiapello, 2005; Klein, 2007). Thus, we appear to be groping around the theoretical universe for some framework that will provide a modicum of order to the chaos we observe. There is induction, deduction, abduction and the middle range. There is a host of isms and ologies from Plato and Aristotle through Kant, Smith and Marx to Habermas, Foucault, Bourdieu and Latour and beyond. Has our application of these isms and ologies had an impact? Do we find ourselves and our constituencies living in more democratically inclined societies? Is public interest at least given equal billing with private interests? Are free speech and religious tolerance more deeply and more widely realized? Is there more freedom from want and fear? And if not, does it mean that we, and others with progressive agendas, have failed? That our

\footnotetext{
${ }^{21}$ One must admit that this is not just (some would say even) an accounting problem.
} 
efforts have been futile? And is there anything else we could have done, can do, or should do in the future?

We also feel quite captured by our prevailing and internalized understandings, rationalities, and knowings. ${ }^{22}$ We are committed to the proposition of the social construction of reality, but we also recognize the reality of the consequences of those constructions. We, as members of a critical research community, are committed to the transformative potential of critique, dialogue and debate but recognize that for this to be the case, certain contextual attributes are needed such as a willingness and ability to communicate and the right to have one's position heard and understood along with an appreciation of the enabling and constraining influence of power and its sources.

Frankly, we do not believe that there is a solution to these contradictions and dilemmas. The modernist, following Habermas, presume a condition where power differentials are suspended and the only power is that of the better argument. The agonistics, following Mouffe (and ultimately Foucault), presume that participants are willing and able to reflexively engage in dialogue with the anticipation of new understandings emerging. We are coming to the realization that the quest for more democratically enabled existence is a utopian dream, albeit a dream that we cannot abandon. As Flyvbjerg (2001) observes regarding Habermas' project and thus modernity, much good has come from the search for first principles over the past two centuries. ${ }^{23}$

We believe much good can come from critical perspectives on accounting research that continues to investigate accounting as it relates to economic, social and environmental (in)justice. We have identified some of the constituencies addressed and suggested fruitful areas for future research such as developing nations, GMS rights, children's rights and animal rights as they represent areas presently under researched located at the edge of economic, social and environmental domains. By moving out of the traditional ways of thinking about issues and constituencies, the potential exists for the emergence of new ways of understanding that lead to innovative ideas and the recognition of unrealized alternatives. However, taking phronetic critical accounting seriously recognizes that there is no single answer to the questions or even an agreed upon version of the questions we are called to explore.

Writing this article has raised many questions in light of the perplexity and complexity of the issues related to accounting and the public interest. In the spirit of phronetic critical accounting and a pluralistic ethos, our purpose is not to resolve these conflicts and contradictions but to provide input for ongoing social dialogue and facilitate further enlightened learning through critical inquiry and debate leading to social praxis. We hope the ideas reviewed and developed will motivate critical reflection in light of one's own lived experience, stimulating research, public discourse and debate regarding alternative, and hopefully better, ideas and interpretations.

\footnotetext{
22 Some might label these "discourses"; however, we do have some aversion to what seems to fast becoming a "false signifier".

${ }^{23}$ And much harm toward which we must be ever vigilant.
} 


\section{References}

Acerete B, Stafford A, Stapleton P. Spanish healthcare public private partnerships: The 'Alzira model'. Critical Perspectives on Accounting 2011; 22(6): 533-549.

Alawattage C, Wickramasinghe D. Appearance of accounting in a political hegemony. Critical Perspectives on Accounting 2008; 19(3): 293-339.

Armstrong P. Budgetary bullying. Critical Perspectives on Accounting 2011; 22(7): 632-643.

Arnold PJ, Cooper C. A tale of two classes: The privatisation of Medway Ports. Critical Perspectives on Accounting 1999; 10(2): 127-152.

Arrington CE, Watkins AL. Maintaining "Critical Intent" Within a Postmodern Theoretical Perspective on Accounting Research. Critical Perspectives on Accounting 2002; 13(2): 139-157.

Arthur A. Exploring an accounting paradigm: The cash account. Critical Perspectives on Accounting 1999; 10(1): 13-35.

Bakre OM. Financial reporting as technology that supports and sustains imperial expansion, maintenance and control in the colonial and post-colonial globalisation: The case of the Jamaican economy. Critical Perspectives on Accounting 2008; 19(4): 487-522.

Belal AR, Cooper S. The absence of corporate social responsibility reporting in Bangladesh. Critical Perspectives on Accounting 2011; 22(7): 654-667.

Benito B, Montesinos V, Bastida F. An example of creative accounting in public sector: The private financing of infrastructures in Spain. Critical Perspectives on Accounting 2008; 19(7): 963-986.

Bengtsson E. Repoliticalization of accounting standard setting-The IASB, the EU and the global financial crisis. Critical Perspectives on Accounting 2011; 22(6): 567-580.

Bernardi RA, Bean DF, Weippert KM. Minority membership on boards of directors: the case for requiring pictures of boards in annual reports. Critical Perspectives on Accounting 2005; 16(8): 1019-1033.

Bessire D, Baker CR. The French Tableau de bord and the American Balanced Scorecard: a critical analysis. Critical Perspectives on Accounting 2005; 16(6): 645-664.

Birkin F. The ecological accountant: From the cogito to thinking like a mountain. Critical Perspectives on Accounting 1996; 7(3): 231-257.

Birkin F, Edwards P, Woodward D. Accounting's contribution to a conscious cultural evolution: an end to sustainable development. Critical Perspectives on Accounting 2005; 16(3): 185-208. 
Bishop M, Boden R. Disabling accounting. Critical Perspectives on Accounting 2008; 19(1): 116.

Blanco RI, de la Rosa D. Hispanics in business education: An under-represented segment of the U.S. population. Critical Perspectives on Accounting 2008; 19(1): 17-39.

Boden R. Figure it out yourself: financial reporting, accountability and the self-employed. Critical Perspectives on Accounting 1999; 10(1): 37-62.

Boltanski L, Chiapello E. The New Spirit of Capitalism. New York: Verso; 2004.

Bourguignon A. Management accounting and value creation: the profit and loss of reification. Critical Perspectives on Accounting 2005; 16(4): 353-389.

Bourguignon A, Chiapello E. The role of criticism in the dynamics of performance evaluation systems.Critical Perspectives on Accounting 2005; 16(6): 665-700.

Boyce G. The social relevance of ethics education in a global(ising) era: From individual dilemmas to systemic crises. Critical Perspectives on Accounting 2008; 19(2): 255-290.

Boyce G. Accounting, ethics and human existence: Lightly unbearable, heavily kitsch. Critical Perspectives on Accounting 2014; 25(3): 197-209.

Briloff A. Accountancy and society a covenant desecrated. Critical Perspectives on Accounting 1990; 1(1): 5-30.

Briloff A. Unaccountable accounting revisited. Critical Perspectives on Accounting 1993; 4(4): 301-335.

Broadbent J, Laughlin R. Accounting Control and Controlling Accounting. Bingley, UK: Emerald; 2013.

Brown J. Democracy, sustainability and dialogic accounting technologies: Taking pluralism seriously. Critical Perspectives on Accounting 2009; 20(3): 313-342.

Brown J, Dillard J. Agonizing over engagement: SEA and the "death of environmentalism" debates. Critical Perspectives on Accounting 2013a; 24(1): 1-18.

Brown J, Dillard J. Critical accounting and communicative action: On the limits of consensual deliberation. Critical Perspectives on Accounting 2013; 24(3): 176-190.

Bryer RA. Double-entry bookkeeping and the birth of capitalism: Accounting for the commercial revolution in Medieval Northern Italy. Critical Perspectives on Accounting 1993; 4(2): 113-140.

Bryer RA. A Marxist critique of the FASB's Conceptual Framework. Critical Perspectives on Accounting 1999; 10(5): 551-589. 
Buhr N. Corporate silence: environmental disclosure and the North American Free Trade Agreement. Critical Perspectives on Accounting 2001; 12(4): 405-421.

Canada J, Kuhn JR, Sutton SG. Accidentally in the public interest: The perfect storm that yielded the Sarbanes-Oxley act. Critical Perspectives on Accounting 2008; 19(7): 987-1003.

Caramanis CV. International accounting firms versus indigenous auditors: Intra-professional conflict in the Greek auditing profession, 1990-1993. Critical Perspectives on Accounting 1999; 10(2): 153-196.

Carnegie GD, West BP. Making accounting accountable in the public sector. Critical Perspectives on Accounting 2005; 16(7): 905-928.

Chabrak N. The politics of transcendence: hermeneutic phenomenology and accounting policy. Critical Perspectives on Accounting 2005; 16(6): 701-716.

Cho C, Roberts RW, Roberts SK. Chinese students in US accounting and business PhD programs: Educational, political and social considerations. Critical Perspectives on Accounting 2008; 19(2): 199-216.

Cho C, Chen JC, Roberts RW. The politics of environmental disclosure regulation in the chemical and petroleum industries: Evidence from the Emergency Planning and Community Right-to-Know Act of 1986. Critical Perspectives on Accounting 2008; 19(4): 450-465.

Chua WF. Teaching and learning only the language of numbers - monolingualism in a multilingual world. Critical Perspectives on Accounting 1996; 7(1): 129-156.

Chwastiak M. Deconstructing the principal-agent model: a view from the bottom. Critical Perspectives on Accounting 1999; 10(4): 425-441.

Chwastiak M. Rendering death and destruction visible: Counting the costs of war. Critical Perspectives on Accounting 2008; 19(5): 573-590.

Ciancanelli P, Gallhofer S, Humphrey C, Kirkham L. Gender and accountancy: Some evidence from the UK. Critical Perspectives on Accounting 1990; 1(2): 117-144.

Cieslewicz JK. Relationships between national economic culture, institutions, and accounting: Implications for IFRS. Critical Perspectives on Accounting 2014; 25(6): 511-528.

Coleman L. Why finance theory fails to survive contact with the real world: A fund manager perspective. Critical Perspectives on Accounting 2014; 25(3): 226-236.

Compin F. The role of accounting in money laundering and money dirtying. Critical Perspectives on Accounting 2008; 19(5): 591-602. 
Conrad L. A structuration analysis of accounting systems and systems of accountability in the privatised gas industry. Critical Perspectives on Accounting 2005; 16(1): 1-26.

Cooper C, Puxty T. On the proliferation of accounting (his)tories. Critical Perspectives on Accounting 1996; 7(3): 285-313.

Cooper C, Puxty T, Robson K, Wilmott H. Changes in the international regulations of auditors: (In)stalling the eighth directive in the UK. Critical Perspectives on Accounting 1996; 7(6): 589613.

Cooper C, Taylor P, Smith N, Catchpowle L. A discussion of the political potential of Social Accounting. Critical Perspectives on Accounting 2005; 16(7): 951-974.

Cousins J, Mitchell A, Sikka P. Auditor liability: The other side of the debate. Critical Perspectives on Accounting 1999; 10(3): 283-312.

Cousins J, Sikka P. Accounting for change: facilitating power and accountability. Critical Perspectives on Accounting 1993; 4(1): 53-72.

Czarniawska B. Humiliation: A standard organizational product? Critical Perspectives on Accounting 2008; 19(7): 1034-1053.

Crawford S, Ferguson J, Helliar CV, Power DM. Control over accounting standards within the European Union: The political controversy surrounding the adoption of IFRS 8. Critical Perspectives on Accounting 2014; 25( 4-5): 304-318.

Cronin B. Economic restructuring in New Zealand: A classical account. Critical Perspectives on Accounting 2008; 19(3): 340-382.

Crowther D, Hosking DM. Accounting in Babel? Constructing social accounting as a multilogical performance. Critical Perspectives on Accounting 2005; 16(5): 535-550.

Davie SK. An autoethnography of accounting knowledge production: Serendipitous and fortuitous choices for understanding our social world. Critical Perspectives on Accounting 2008; 19(7): 1054-1079.

Davila T, Oyon D. Cross-paradigm collaboration and the advancement of management accounting knowledge. Critical Perspectives on Accounting 2008; 19(6): 887-893.

Dellaportas S, Davenport L. Reflections on the public interest in accounting. Critical Perspectives on Accounting 2008; 19(7): 1080-1098.

Dillard J. Accounting as a Critical Social Science. Accounting, Auditing and Accountability Journal 1991; 4(1): 8-28. 1991. 
Dillard J, Roslender R. Taking pluralism seriously: Embedded moralities in management accounting and control systems. Critical Perspectives on Accounting 2011; 22(2): 135-147.

Dillard J, Tinker T. Commodifying business and accounting education: The implications of accreditation. Critical Perspectives on Accounting 1996; 7(1): 215-225.

Dixon K, Gaffikin M. Accounting practices as social technologies of colonialistic outreach from London, Washington, et Cetera. Critical Perspectives on Accounting 2014; 25(8), 683-708.

Dominelli L, Hoogvelt A. Globalisation, the privatization of welfare, and the changing role of professional academics in Britain. Critical Perspectives on Accounting 1996; 7(1): 191-212.

Duff A, Ferguson J. Disability and the socialization of accounting professionals. Critical Perspectives on Accounting 2011; 22(4): 351-364.

Everett J, Green D, Neu D. Independence, objectivity and the Canadian CA profession. Critical Perspectives on Accounting 2005; 16(4): 415-440.

Everett J, Tremblay MS. Ethics and internal audit: Moral will and moral skill in a heteronomous field. Critical Perspectives on Accounting 2014a; 25(3): 181-196.

Everett J, Tremblay MS. On hypocrisy, the phronemos, and kitsch: A reply to our commentators. Critical Perspectives on Accounting 2014b; 25(3): 222-225.

Ezzamel M, Hyndman N, Johnsen A, Lapsley I. Reforming central government: An evaluation of an accounting innovation. Critical Perspectives on Accounting 2014; 25(4-5): 409-422.

Findlay MC, Williams EE. A post Keynesian view of modern financial economics: In search of alternative paradigms'. Journal of Business Finance and Accounting 1985; 12(1): 1-18.

Flyvbjerg B. Social science that matters: Why social inquiry fails and how it can succeed again. Cambridge: Cambridge University Press; 2001.

Freedman M, Stagliano AJ. Environmental disclosures: electric utilities and Phase 2 of the Clean Air Act. Critical Perspectives on Accounting 2008; 19(4): 466-486.

Gallhofer S, Haslam J, Kim SN, Mariu S. Attracting and retaining Maori students in accounting: Issues, experiences and ways forward. Critical Perspectives on Accounting 1999; 10(6): 773807.

Gibson K. The problems with reporting pollution allowances: Reporting is not the problem. Critical Perspectives on Accounting 1996; 7(6): 655-665.

Gleadle P, Cornelius N. A case study of financialization and EVA®. Critical Perspectives on Accounting 2008; 19(8): 1219-1238. 
Gray R, Brennan A, Malpas J. New account: Towards a reframing of social accounts. Accounting Horizons 2014; 38(4): 258-273.

Gray R, Collison D. Can't see the wood for the trees, can't see the trees for the numbers? Accounting education, sustainability and the Public Interest. Critical Perspectives on Accounting 2002; 13(5-6): 797-836.

Grinnell DJ, Hunt HG III. Gifted pollution allowances: recognizing a liability to society. Critical Perspectives on Accounting 2002; 13(2): 211-228.

Gurd B. Structuration and middle-range theory-A case study of accounting during organizational change from different theoretical perspectives. Critical Perspectives on Accounting 2008; 19(4): 523-543.

Haynes K. Transforming identities: Accounting professionals and the transition to motherhood. Critical Perspectives on Accounting 2008; 19(5): 620-642.

Hoffmann S, Zülch H. Lobbying on accounting standard setting in the parliamentary environment of Germany. Critical Perspectives on Accounting 2014; 25(8): 709-723.

Hooper K, Kearins K. The walrus, carpenter and oysters: Liberal reform, hypocrisy and expertocracy in Maori land loss in New Zealand 1885-1911. Critical Perspectives on Accounting 2008; 19(8):1239-1262.

Humphrey C, Lewis L, Owen D. Still too distant voices? Conversations and reflections on the social relevance of accounting education. Critical Perspectives on Accounting 1996; 7(1): 77-99.

Hudson R, Keasey K, Littler K, Dempsey M. Time diversification: An essay on the need to revisit finance theory. Critical Perspectives on Accounting 1999; 10(4): 501-519.

Inanga EL, Schneider WB. The failure of accounting research to improve accounting practice: a problem of theory and lack of communication. Critical Perspectives on Accounting 2005; 16(3): 227-248.

James K. A Critical Theory perspective on the pressures, contradictions and dilemmas faced by entry-level accounting academics. Critical Perspectives on Accounting 2008; 19(8): 1263-1295.

Jayasinghe K, Wickramasinghe D. Power over empowerment: Encountering development accounting in a Sri Lankan fishing village. Critical Perspectives on Accounting 2011; 22(4): 396414.

Jeacle I. A practice of her own: Female career success beyond the accounting firm. Critical Perspectives on Accounting 2011; 22(3): 288-303. 
Jensen RE. Working within neoclassical theory and "modern theory" of finance to detect and measure monopoly power components of ex post accounting rate of return. Critical Perspectives on Accounting 1990; 1(1): 69-101.

Kim SN. Whose voice is it anyway? Rethinking the oral history method in accounting research on race, ethnicity and gender. Critical Perspectives on Accounting 2008; 19(8): 1346-1369.

Klein N. The shock doctrine. New York: Picador; 2007.

Lambert C, Sponem S. Corporate governance and profit manipulation: a French field study. Critical Perspectives on Accounting 2005; 16(6): 717-748.

Lawrence S. From welfare state to the civil society: The constitutive use of accounting in the reform of the NZ public sector. Critical Perspectives on Accounting 1999; 10(2): 223-246.

Lawrence S, Sharma U. Commodification of education and academic labour - Using the Balanced Scorecard in a university setting. Critical Perspectives on Accounting 2002; 13(5-6): 661-677.

Lee TA, Clarke F, Dean G. The dominant senior manager and the reasonably careful, skilful, and cautious auditor. Critical Perspectives on Accounting 2008; 19(5):677-711.

Lee TA, Williams PF. Accounting from the inside: Legitimizing the accounting academic elite. Critical Perspectives on Accounting 1999; 10(6): 867-895.

Lehman G. Environmental accounting: Pollution permits or selling the environment. Critical Perspectives on Accounting 1996; 7(6): 667-676.

Lehman G. A critical perspective on the harmonisation of accounting in a globalising world. Critical Perspectives on Accounting 2005; 16(7): 975-992.

Lehman G. Moral will, accounting and the phronemos. Critical Perspectives on Accounting 2014; 25(3): 210-216.

Lehman CR, Okcabol F. Accounting for crime. Critical Perspectives on Accounting 2005; 16(5): 613-639.

Linsley PM, Shrives PJ. Douglasian cultural dialogues and the Financial Reporting Council complexity project. Critical Perspectives on Accounting 2014; 25(8): 757-770.

Low M, Davey H, Hooper K. Accounting scandals, ethical dilemmas and educational challenges. Critical Perspectives on Accounting; 19(2): 222-254.

MacLullich KK, Sucher P. A local realisation of auditor independence construct in Poland: counteracting 'iron curtain' syndrome in academic writing. Critical Perspectives on Accounting 2005; 16(5): 593-612. 
Martens S, Stevens KT. Positive Accounting Theory and the obligation for post-retirement benefits. Critical Perspectives on Accounting 1993; 4(3): 275-295.

McGoun EG. A re-evaluation of market efficiency measurement. Critical Perspectives on Accounting 1990; 1(3): 263-274.

McGoun EG. The CAPM: A Nobel failure. Critical Perspectives on Accounting 1993; 4(2): 155177.

McGowan S, Potter L. The implications of the Chinese learner for the internationalization of the curriculum: An Australian perspective. Critical Perspectives on Accounting 2008; 19(2): 181198.

McNicholas P, Barrett M. Answering the emancipatory call: an emerging research approach 'on the margins' of accounting. Critical Perspectives on Accounting 2005; 16(4): 391-414.

McPhail K. The threat of ethical accountants: An application of Foucault's concept of ethics to accounting education and some thoughts on ethically educating for the other. Critical Perspectives on Accounting 1999; 10(6): 833-866.

Mellett $\mathrm{H}$. The consequences and causes of resource accounting. Critical Perspectives on Accounting 2002; 13(2): 231-254.

Mihret DG. How can we explain internal auditing? The inadequacy of agency theory and a labor process alternative. Critical Perspectives on Accounting 2014; 25(8): 771-782.

Miller MC. Auditor liability and the development of a strategic evaluation of going concern. Critical Perspectives on Accounting 1999; 10(3): 355-375.

Milne M. Capitalizing and appropriating society's rights to clean air: A comment on Wambsganss \& Sanford's accounting proposal. Critical Perspectives on Accounting 1996; 7(6): 681-695.

Milne M. Positive accounting theory, political costs and social disclosure analyses: a critical look. Critical Perspectives on Accounting 2002; 13(3): 369-395.

Milne MJ, Gray R. W(h)ither ecology? The triple bottom line, the Global Reporting Initiative, and corporate sustainability reporting. Journal of Business Ethics 2013; 118(1): 13-29.

Mitchell A, Sikka, P. Accounting for change: The institutions of accountancy. Critical Perspectives on Accounting 1993; 4(1): 29-52.

Morales J, Gendron Y, Guénin-Paracini H. State privatization and the unrelenting expansion of neoliberalism: The case of the Greek financial crisis. Critical Perspectives on Accounting 2014; 25(6): 423-445. 
Moriceau JL. What can we learn from a singular case like Enron? Critical Perspectives on Accounting 2005; 16(6): 787-796.

Mouffe C. The democratic paradox. London: Verso; 2000.

Mouffe C. On the political. London: Routledge; 2005.

Mouffe C. Agonistics: Thinking the world politically. New York: Verso; 2013.

Neu D, Simmons C. Reconsidering the "social" in Positive Accounting Theory: The case of site restoration costs. Critical Perspectives on Accounting 1996; 7(4): 409-435.

Neu D, Taylor A. Accounting and the politics of divestment. Critical Perspectives on Accounting 1996; 7(4): 437-460.

Nibert DA. Animal oppression and human violence. Domesecration, capitalism, and global conflict. New York: Columbia University Press; 2013.

Nickell EB, Roberts RW. Organizational legitimacy, conflict, and hypocrisy: An alternative view of the role of internal auditing. Critical Perspectives on Accounting 2014; 25(3): 217-221.

Ogden SG. The limitations of agency theory: The case of accounting-based profit sharing schemes. Critical Perspectives on Accounting 1993; 4(2): 179-206.

Ogden SG, Anderson F. The role of accounting in organizational change: Promoting performance improvements in the privatized UK water industry. Critical Perspectives on Accounting 1996; 10(1): 91-124.

Oguri T. Functions of accounting and accounting regulation: alternative perspectives based on Marxian economics. Critical Perspectives on Accounting 2005; 16(2): 77-94.

Oldroyd D, Fleischman RK, Tyson TN. The culpability of accounting practice in promoting slavery in the British Empire and antebellum United States. Critical Perspectives on Accounting 2008; 19(5): 764-784.

Otusanya OJ. The role of multinational companies in tax evasion and tax avoidance: The case of Nigeria. Critical Perspectives on Accounting 2011; 22(3): 316-332.

Regan T. The case for animal rights. Oakland: University of California Press; 1985.

Reiter SA. The Kohlberg-Gilligan controversy: Lessons for accounting ethics education. Critical Perspectives on Accounting 1996; 7(1): 33-54.

Riotto J. Understanding the Sarbanes-Oxley Act-A valued added approach for public interest. Critical Perspectives on Accounting 2008; 19(7): 952-962. 
Rosen M. Staying on the string: The YO and the market in eighty-nine. Critical Perspectives on Accounting 1990; 1(4): 337-365.

Roslender R. Relevance lost and found: Critical perspectives on the promise of management accounting. Critical Perspectives on Accounting 1996; 7(5): 533-561.

Roslender R, Dillard J. Reflections on the Interdisciplinary Perspectives on Accounting Project. Critical Perspectives on Accounting 2003; 14(3): 325-352.

Saravanamuthu K. Reflecting on the Biggs-Watkins theory of the Chinese learner. Critical Perspectives on Accounting 2008; 19(2): 138-180.

Schwartz BN, Williams S, Williams PF. US doctoral students' familiarity with accounting journals: insights into the structure of the US academy. Critical Perspectives on Accounting 2005; 16(3): 327-348.

Shaoul J. A critical financial analysis of the Private Finance Initiative: selecting a financing method or allocating economic wealth? Critical Perspectives on Accounting 2005; 16(4): 441471.

Shapiro B. Rash Words, insincere assurances, uncertain promises: verifying employers' intentions in labour contracts. Critical Perspectives on Accounting 2002; 13(1): 63-88.

Soufian M, Forbes W, Hudson R. Adapting financial rationality: Is a new paradigm emerging? Critical Perspectives on Accounting 2014; 25(8): 724-742.

Spence C, Carter D. Accounting for the General Intellect: Immaterial labour and the social factory. Critical Perspectives on Accounting 2011; 22(3): 304-315.

Stoianoff, NP, Kaidonis MA. Rehabilitation of mining sites: do taxation and accounting systems legitimise the privileged or serve the community? Critical Perspectives on Accounting 2005; 16(1): 47-59.

Thomson I, Bebbington J. Social and environmental reporting in the UK: a pedagogic evaluation. Critical Perspectives on Accounting 2005; 16(5): 507-533.

Thomson, I., Russell, S., Dey, C. Activism, arenas and accounts in conflicts over tobacco control. Accounting, Auditing \& Accountability Journal (in press).

Touron P. The adoption of US GAAP by French firms before the creation of the International Accounting Standard Committee: an institutional explanation. Critical Perspectives on Accounting 2005; 16(6): 851-873.

Townley B. Accounting in detail: Accounting for individual performance. Critical Perspectives on Accounting 1996; 7(5): 565-584. 
Tremblay MS, Gendron Y. Governance prescriptions under trial: On the interplay between the logics of resistance and compliance in audit committees. Critical Perspectives on Accounting 2011; 22(3): 259-272.

Walker SP. Ethel Ayres Purdie: Critical practitioner and suffragist. Critical Perspectives on Accounting 2011; 22(1): 79-101.

Wickramasinghe D, Hopper T. A cultural political economy of management accounting controls: a case study of a textile Mill in a traditional Sinhalese village. Critical Perspectives on Accounting 2005; 16(4): 473-503.

Whittle A, Carter C, Mueller F. 'Above the fray': Interests, discourse and legitimacy in the audit field. Critical Perspectives on Accounting 2014; 25(8): 783-802.

Zhang Y, Andrew J. Financialisation and the Conceptual Framework. Critical Perspectives on Accounting 2014; 25(1): 17-26. 
APPENDIX Thematic categorization of selected CPA articles 1990-2014

\begin{tabular}{|c|c|c|c|c|c|}
\hline Profession & Standard-setting & Theories & \multicolumn{2}{|c|}{ Ideologies } & NPM \\
\hline Briloff, 1990 & Hunt \& Holger, 1990 & Jensen, 1990 & Dillard \& Nehmer, 1990 & Alawattage \& & Laughlin \& Broadbent, \\
\hline Ponemon, 1990 & Committe, 1990 & McGoun, 1990 & Murray \& Knights, 1990 & Wickramasinghe, 2008 & 1993 \\
\hline Mitchell \& Sikka, 1993 & Robson, 1993 & Rosen, 1990 & Humphrey \& Moizer, 1990 & Cronin, 2008 & Townley, 1996 \\
\hline Briloff, 1993 & Cousins \& Sikka, 1993 & McGoun, 1993 & Lukka, 1990 & Bakre, 2008 & Ogden \& Anderson, 1999 \\
\hline Walker, 1993 & Ohsawa \& Tinker, 1993 & Ogden, 1993 & Funnell, 1990 & Murphy, 2008 & Arnold \& Cooper, 1999 \\
\hline Davis \& Strawser, 1993 & Cooper et al., 1996 & Martens \& Stevens, 1993 & Bryer, 1993 & Everett, 2008 & Caramanis, 1999 \\
\hline Hooks \& Moon, 1993 & Bryer, 1999 & Gangolly \& Hussein, 1996 & Hooper \& Pratt, 1993 & Gleadle \& Cornelius, 2008 & Lawrence, 1999 \\
\hline Briloff, 1993 & Macve, 1999 & Neu \& Simmons, 1996 & Munro \& Hatherly, 1993 & Jeacle, 2008 & Edwards et al., 1999 \\
\hline Hanlon, 1996 & Robson, 1999 & Wambsganss \& Sanford, 1996 & Chwastiak, 1996 & Nagy \& Robb, 2008 & Zan, 2002 \\
\hline Seal et al., 1996 & Samuelson, 1999 & Chwastiak, 1999 & Neu \& Taylor, 1996 & Dillard \& Roslender, 2011 & Davies \& Thomas, 2002 \\
\hline Briloff, 1999 & Whittington, 1999 & Hudson et al., 1999 & Fogarty \& Ruhl, 1996 & Spence \& Carter, 2011 & Mellett, 2002 \\
\hline Cousins et al., 1999 & Bryer, 1999 & Milne, 2002 & Dempsey, 1996 & Otusanya, 2011 & Conrad, 2005 \\
\hline Fuerman, 1999 & Shapiro, 2002 & Yamaji, 2005 & Lee, 1999 & Banyi et al., 2011 & Shaoul, 2005 \\
\hline Green,1999 & Sawabe, 2002 & Chabrak, 2005 & Chwastiak, 1999 & Farrar, 2011 & Carnegie \& West, 2005 \\
\hline Miller, 1999 & Ishikawa, 2005 & Lambert \& Sponem, 2005 & Lee \& Williams, 1999 & Gallhofer et al., 2011 & Collier, 2005 \\
\hline Peck, 1999 & MacLullich \& Sucher, 2005 & Haynes et al., 2008 & Baker, 2002 & Collison et al., 2014 & Benito et al., 2008 \\
\hline Ward, 1999 & Touron, 2005 & Bay, 2011 & Humphrey, 2002 & Gleadle, 2014 & Khadaroo, 2008 \\
\hline Catchpowle \& Cooper, 1999 & Raar, 2008 & Coleman, 2014 & Filling et al., 2002 & Andersson, 2014 & Gårseth-Nesbakk, 2011 \\
\hline Cullinan \& Sutton, 2002 & Walters \& Young, 2008 & Froud et al., 2014 & Armstrong, 2002 & Maltby, 2014 & Parker, 2011 \\
\hline Baker \& Owsen, 2002 & Daugherty \& Tervo, 2008 & Mihret, 2014 & Drennan \& Kelly, 2002 & Everett \& Tremblay, 2014 & Acerete et al., 2011 \\
\hline Everett et al., 2005 & Riotto, 2008 & Soufian et al., 2014 & Ezzamel \& Hoskin, 2002 & Bruns, 2014 & Muniesa \& Linhardt, 2011 \\
\hline Bakre, 2005 & Canada et al., 2008 & & Oguri. 2005 & Puyou, 2014 & Toms et al., 2011 \\
\hline DiGabriele, 2008 & Briloff, 2008 & & Jinnai, 2005 & Bakre, 2014 & Becker et al., 2014 \\
\hline Radcliffe, 2008 & Fox, 2008 & & Chand, 2005 & Dixon \& Gaffikin, 2014 & Beverungen et al., 2014 \\
\hline Lee et al., 2008 & Masters-Stout et al., 2008 & & Shapiro, 2005 & & Ferri \& Zan, 2014 \\
\hline Newberry \& Robb, 2008 & Okamoto, 2011 & & Schwartz et al., 2005 & & Hyndman et al., 2014 \\
\hline Dellaportas \& Davenport, & Bengtsson, 2011 & & Bourguignon, 2005 & & Ezzamel et al., 2014 \\
\hline 2008 & Zhang \& Andrew, 2014 & & Pesqueux, 2005 & & Morales et al., 2014 \\
\hline McKinstry, 2008 & Siepel \& Nightingale, 2014 & & Lehman, 2005 & & \\
\hline Funnell, 2011 & Oulasvirta, 2014 & & Broadbent et al., 2008 & & \\
\hline Hasseldine, Holland \& van & Crawford et al., 2014 & & & & \\
\hline der Rij, 2011 & Carnegie \& O’Connell, 2014 & & & & \\
\hline Radcliffe, 2011 & Albu et al., 2014 & & & & \\
\hline Boyce, 2014 & Cieslewicz, 2014 & & & & \\
\hline Lehman, 2014 & Eckersley et al., 2014 & & & & \\
\hline Nickell \& Roberts, 2014 & Müller, 2014 & & & & \\
\hline Everett \& Tremblay, 2014 & Hoffman \& Zülch, 2014 & & & & \\
\hline Edgle, 2014 & & & & & \\
\hline Dellaportas, 2014 & & & & & \\
\hline
\end{tabular}




\begin{tabular}{|c|c|c|c|c|c|c|}
\hline Accounting education & \multicolumn{2}{|c|}{ Accounting research } & Labor & Other underrepresented & SEA \& CRS & Corporate governance \\
\hline $\begin{array}{l}\text { Gallhofer \& Haslam, } \\
1996 \\
\text { Reiter, } 1996 \\
\text { Amernic, } 1996 \\
\text { Humphrey et al., } 1996 \\
\text { Paisey \& Paisey, } 1996 \\
\text { Chua, 1996 } \\
\text { Davis \& Sherman, } 1996 \\
\text { Dominelli \& Hoogvelt, } \\
\text { 1996 } \\
\text { Dillard \& Tinker, } 1996 \\
\text { Arnold, 1999 } \\
\text { Cllarke et al., 1999 } \\
\text { Gallhofer et al., } 1999 \\
\text { McPhail, 1999 } \\
\text { Tilling, 2002 } \\
\text { Boyce, 2002 } \\
\text { Parker, 2002 } \\
\text { Dillard, } 2002 \\
\text { Churchman, 2002 } \\
\text { Singh, 2002 } \\
\text { Neumann \& Guthrie, } \\
\text { 2002 } \\
\text { Juniper, 2002 } \\
\text { Gray \& Collison, } 2002 \\
\text { Daly, 2005 } \\
\text { Saravanamuthu, } 2008 \\
\text { McGowan \& Potter, } \\
\text { 2008 } \\
\text { Cho et al., 2008 } \\
\text { Low et al., 2008 } \\
\text { Boyce, 2008 } \\
\text { Lucas, 2008 } \\
\text { James, 2008 }\end{array}$ & $\begin{array}{l}\text { Neimark, 1990 } \\
\text { Arthur,1999 } \\
\text { Broadbent et al., } 1996 \\
\text { Fleischman et al., } 1996 \\
\text { Roslender, 1996 } \\
\text { Clarke et al., 1999 } \\
\text { Arrington \& Watkins, } \\
\text { 2002 } \\
\text { Bay, 2002 } \\
\text { Broadbent, 2002 } \\
\text { Cooper, 2002 } \\
\text { Fujita, 2002 } \\
\text { Mouritsen et al., 2002 } \\
\text { Oguri, 2002 } \\
\text { Tinker, 2002 } \\
\text { Vagnoni, 2002 } \\
\text { Watts, 2002 } \\
\text { Yashimi, 2002 } \\
\text { Inanga \& Schneider, } \\
\text { 2005 } \\
\text { Moriceau, 2005 } \\
\text { LeTheule \& Fronda, } \\
\text { 2005 } \\
\text { Gurd, 2008 } \\
\text { Ahrens et al., 2008 } \\
\text { Armstrong, 2008 } \\
\text { Baxter et al., 2008 } \\
\text { Davila \& Oyon, 2008 } \\
\text { Dillard, 2008 } \\
\text { Merchant, 2008 } \\
\text { Parker, 2008 } \\
\text { Scapens, 2008 } \\
\text { Willmott, 2008 } \\
\text { Davie, 2008 } \\
\text { Englund \& Gerdin, } \\
\text { 2008 } \\
\text { Kim, 2008 }\end{array}$ & $\begin{array}{l}\text { Nouri \& Kyj, } 2008 \\
\text { Baker, 2011 } \\
\text { Everett, } 2011 \\
\text { Martinez, } 2011 \\
\text { Mouritsen, 2011 } \\
\text { Heidhues \& Patel, } \\
2011 \\
\text { Molisa, 2011 } \\
\text { Carter \& Spence, } \\
2011 \\
\text { Dillard \& Reynolds, } \\
2011 \\
\text { Gallhofer \& Haslam, } \\
2011 \\
\text { Jacobs, 2011 } \\
\text { McPhail, 2011 } \\
\text { Englund \& Gerdin, } \\
2011 \\
\text { Samuel \& Manassian, } \\
\text { 2011 } \\
\text { McKernan, 2011 } \\
\text { Bay et al., } \\
\text { 2014 } \\
\text { Porporato, 2014 } \\
\text { Conrad, 2014 } \\
\text { Roberts, 2014 } \\
\text { Coad \& Glyptis, } 2014 \\
\text { Englund \& Gerdin, } \\
\text { 2014 } \\
\text { Boll, 2014 } \\
\text { Cooper \& Coulson, } \\
\text { 2014 } \\
\text { Linsley \& Shrives, } \\
\text { 2014 } \\
\text { Whittle et al., 2014 }\end{array}$ & $\begin{array}{l}\text { Cooper \& Puxty, } 1996 \\
\text { Roslender, } 1996 \\
\text { Hanlon, 1999 } \\
\text { Lammont \& Lucas, } \\
1999 \\
\text { Lawrence \& Sharma, } \\
2002 \\
\text { Wickramasinghe \& } \\
\text { Hopper, 2005 } \\
\text { Harney, 2005 } \\
\text { Bessire \& Baker, } 2005 \\
\text { Bourguignon \& } \\
\text { Chiapello, 2005 } \\
\text { Carmona \& Gutiérrez, } \\
\text { 2005 } \\
\text { Johansen, 2008 } \\
\text { Czarniawska, 2008 } \\
\text { James, 2008 } \\
\text { Alawattage, } 2011 \\
\text { Masrani \& McKiernan, } \\
\text { 2011 } \\
\text { Armstrong, } 2011\end{array}$ & $\begin{array}{l}\text { Ciancanelli et al., } 1990 \\
\text { Boden, 1999 } \\
\text { Oberholzer, 2005 } \\
\text { McNicholas \& Barrett, } \\
2005 \\
\text { Davie, 2005 } \\
\text { Bernardi et al., 2005 } \\
\text { Blanco \& de la Rosa, } \\
2008 \\
\text { Haynes, } 2008 \\
\text { Oldroyd et al., 2008 } \\
\text { Fearfull et al., 2008 } \\
\text { Hooper \& Kearins, } 2008 \\
\text { Duff, 2011 } \\
\text { Kuasirikun, 2011 } \\
\text { Walker, 2011 } \\
\text { Jeacle, 2011 } \\
\text { Duff \& Ferguson, } 2011 \\
\text { Jayasinghe \& } \\
\text { Wickramasinghe, } 2011 \\
\text { Harney, 2011 } \\
\text { Baker, 2014 }\end{array}$ & $\begin{array}{l}\text { Birkin, } 1996 \\
\text { Gibson, } 1996 \\
\text { Lehman, } 1996 \\
\text { Milne, } 1996 \\
\text { Lewis \& Unerman, } 1999 \\
\text { Buhr, 2001 } \\
\text { Grinnell \& Hunt, 2002 } \\
\text { Stoianoff \& Kaidonis, } \\
2005 \\
\text { Birkin et al., } 2005 \\
\text { Thomson \& Bebbington, } \\
\text { 2005 } \\
\text { Crowther \& Hosking, } \\
\text { 2005 } \\
\text { Cooper et al., 2005 } \\
\text { Kuasirikun, 2005 } \\
\text { Catasús, 2008 } \\
\text { Patten \& Freedman, } \\
\text { 2008 } \\
\text { Cho et al., 2008 } \\
\text { Freedman \& Stagliano, } \\
\text { 2008 } \\
\text { Chwastiak, 2008 } \\
\text { Himick, 2011 } \\
\text { Moore, 2011 } \\
\text { Belal \& Cooper, } 2011 \\
\text { Carter et al., 2011 }\end{array}$ & $\begin{array}{l}\text { Lehman \& Okcabol, } \\
2005 \\
\text { Rezaee, 2005 } \\
\text { Bishop \& Boden, } 2008 \\
\text { Compin, 2008 } \\
\text { Epps \& Cereola, } 2008 \\
\text { Guidi et al., 2008 } \\
\text { Tremblay \& Gendron, } \\
2011 \\
\text { Cooper et al., } 2011 \\
\text { Chetty, 2011 } \\
\text { Frankental, } 2011 \\
\text { Gallhofer et al., } 2011 \\
\text { Gray \& Gray, 2011 } \\
\text { Islam \& McPhail, } 2011 \\
\text { Sikka, 2011 } \\
\text { Yapa, 2014 }\end{array}$ \\
\hline
\end{tabular}


APPENDIX 2 Number of articles in each of the main themes
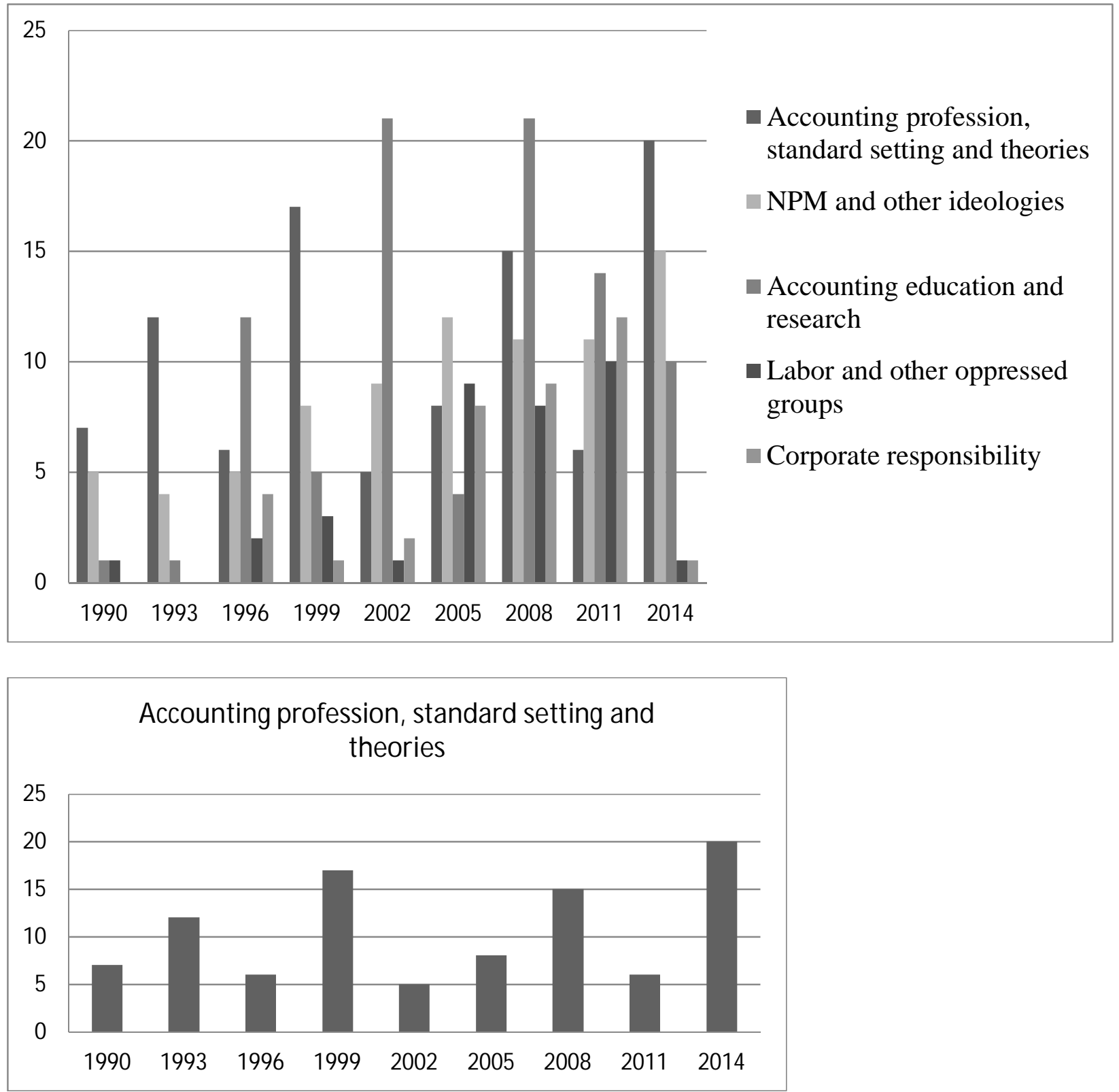

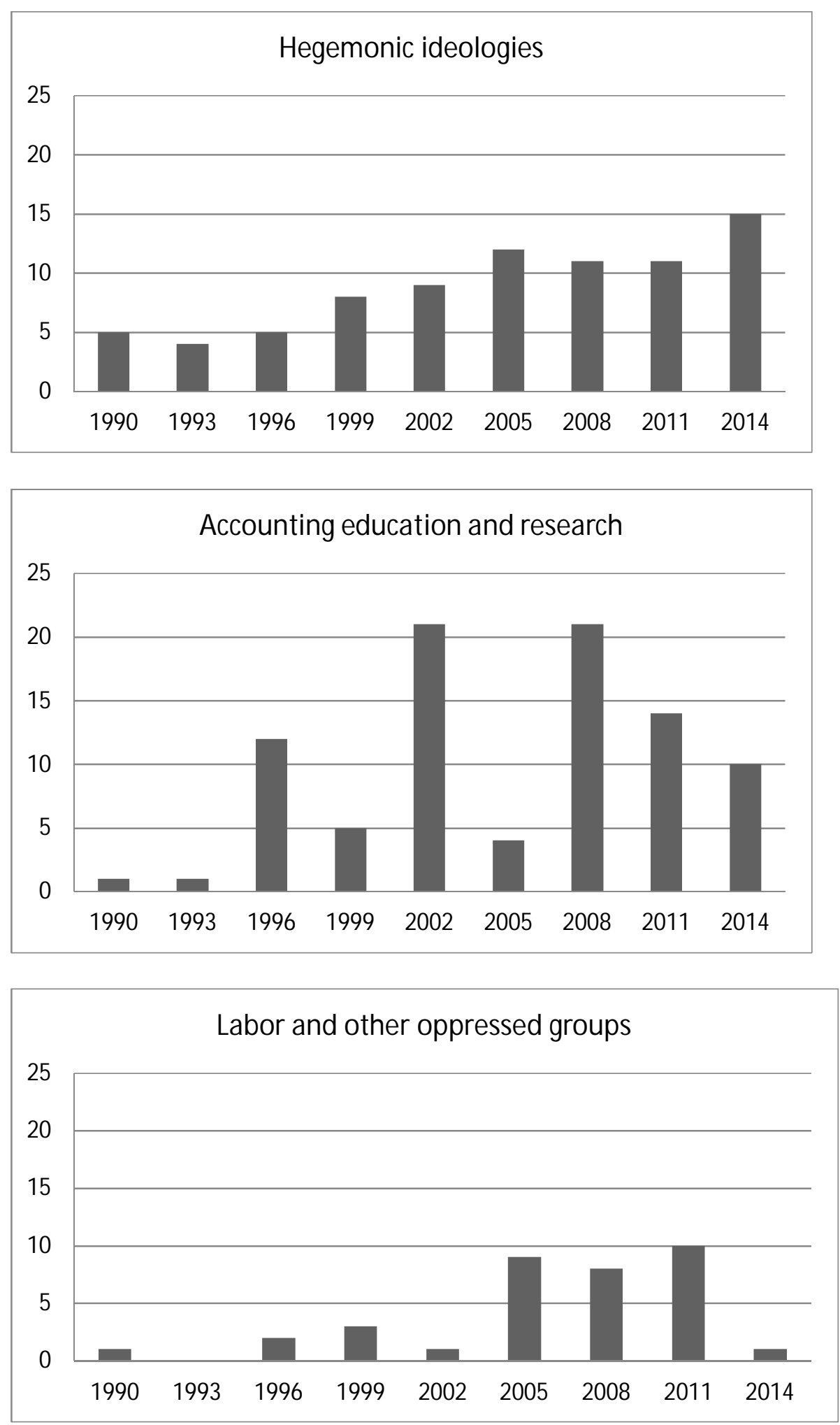


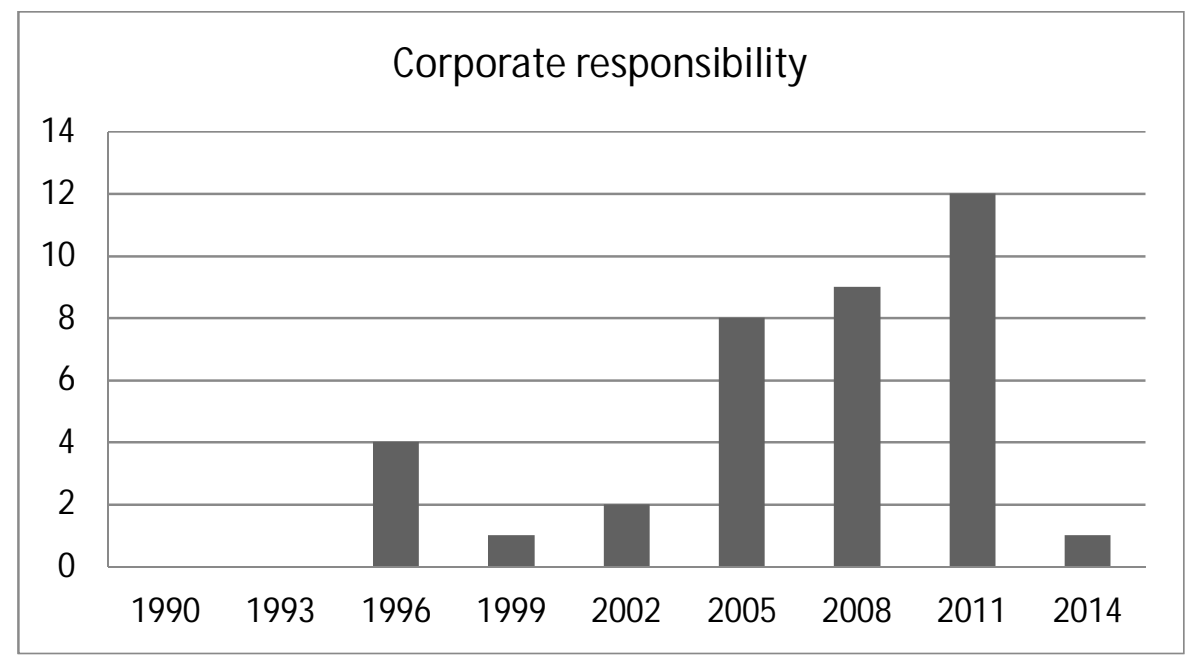


Table 1. Summary of the phronetic features of exemplar articles

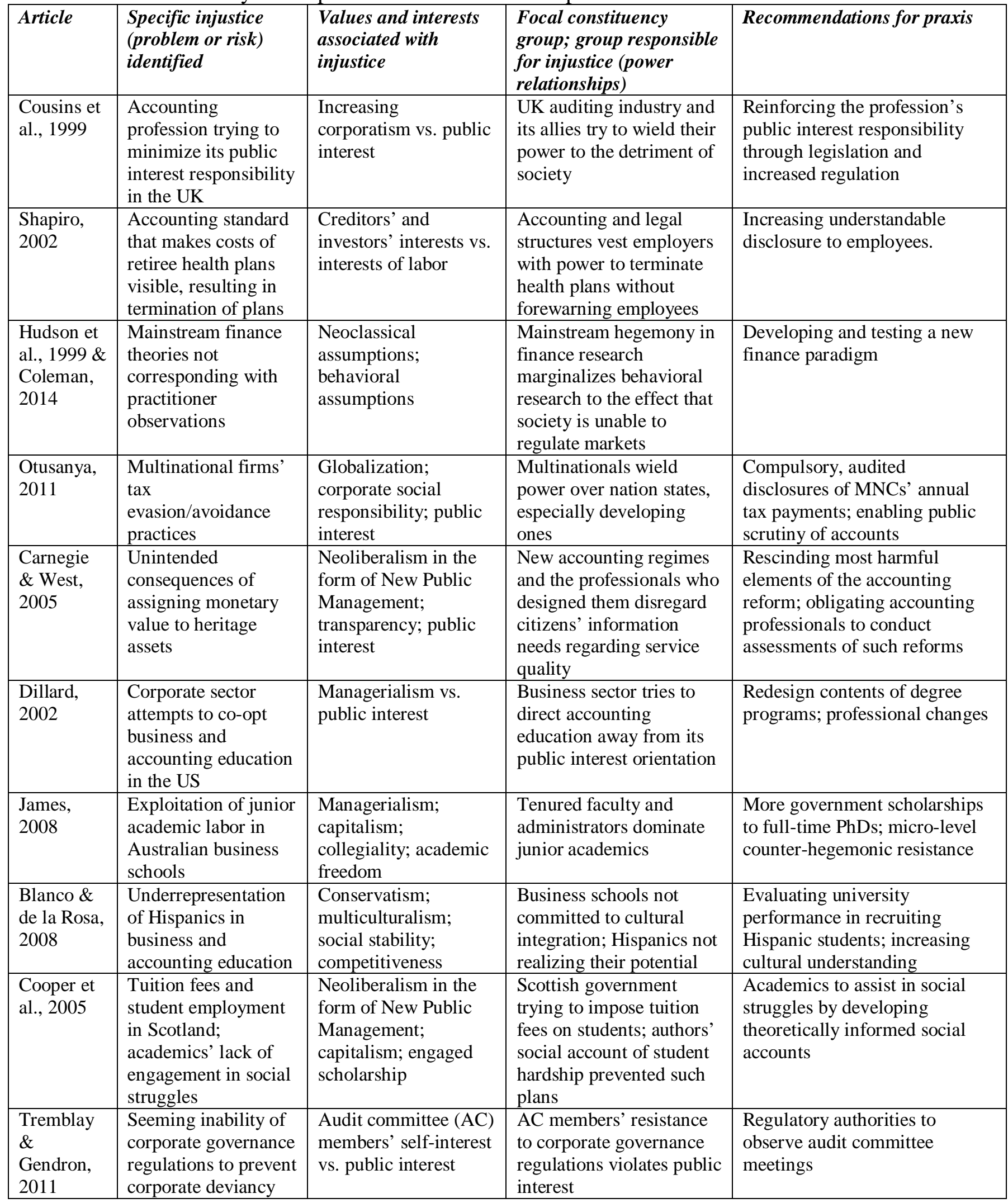

